Article

\title{
The AMERIGO Lander and the Automatic Benthic Chamber (CBA): Two New Instruments to Measure Benthic Fluxes of Dissolved Chemical Species ${ }^{\dagger}$
}

\author{
Federico Spagnoli ${ }^{1, *(\mathbb{D}}$, Pierluigi Penna ${ }^{1} \mathbb{D}$, Giordano Giuliani $^{1}{ }^{1}$, Luca Masini ${ }^{2}$ \\ and Valter Martinotti ${ }^{3}$ \\ 1 Istituto per le Risorse Biologiche e le Biotecnologie Marine (IRBIM), Consiglio Nazionale delle \\ Ricerche (CNR), Ancona 60125, Italy; pierluigi.penna@cnr.it (P.P.); giordano.giuliani@cnr.it (G.G.) \\ 2 Institute for Microelectronics and Microsystems, Consiglio Nazionale delle Ricerche, Bologna 40129, Italy; \\ masini@bo.imm.cnr.it \\ 3 Dipartimento Sviluppo sostenibile e Fonti Energetiche, RSE SpA, Milano 20134, Italy; \\ valter.martinotti@rse-web.it \\ * Correspondence: federico.spagnoli@cnr.it; Tel.: +39-071-2078847 \\ $+\quad$ This paper is an extended version of paper published in Spagnoli, F.; Giuliani, G.; Martinotti, V.; Masini, L.; \\ Penna, P. AMERIGO and CBA: A new lander and a new automatic benthic chamber for dissolved benthic \\ flux measurements. In Proceedings of the 2018 IEEE International Workshop on Metrology for the Sea; \\ Learning to Measure Sea Health Parameters (MetroSea), Bari, Italy, 8-10 October 2018.
}

Received: 28 April 2019; Accepted: 5 June 2019; Published: 10 June 2019

\begin{abstract}
Marine environments are currently subject to strong ecological pressure due to local and global anthropic stressors, such as pollutants and atmospheric inputs, which also cause ocean acidification and warming. These strains can result in biogeochemical cycle variations, environmental pollution, and changes in benthic-pelagic coupling processes. Two new devices, the Amerigo Lander and the Automatic Benthic Chamber (CBA), have been developed to measure the fluxes of dissolved chemical species between sediment and the water column, to assess the biogeochemical cycle and benthic-pelagic coupling alterations due to human activities. The Amerigo Lander can operate in shallow as well as deep water (up to $6000 \mathrm{~m}$ ), whereas the CBA has been developed for the continental shelf (up to $200 \mathrm{~m}$ ). The lander can also be used to deploy a range of instruments on the seafloor, to study the benthic ecosystems. The two devices have successfully been tested in a variety of research tasks and environmental impact assessments in shallow and deep waters. Their measured flux data show good agreement and are also consistent with previous data.
\end{abstract}

Keywords: lander; benthic chambers; benthic fluxes of dissolved chemical species; marine technology; marine instrumentation

\section{Introduction}

Marine environments are affected by strong ecosystem stressors that include direct human activities (e.g., marine traffic, offshore activities, mining, coastal works) and inputs (e.g., dumping of solid waste on the seafloor, anthropic inputs transported by rivers, ballast water discharge) and chemical and climate changes that act on a global scale (e.g., raised $\mathrm{CO}_{2}$ levels and air temperature). These stressors affect marine chemistry and processes by inducing ocean acidification, global sea warming, and changes in hydrological and biogeochemical cycles [1]. Human activities also result in an increased supply of trophic substances, which, in some environmental settings such as shallow enclosed seas with low hydrodynamics, can lead to dystrophic crises [2-4]. These stressors also have the potential to alter the biogeochemical cycles of elements such as carbon, phosphorus, nitrogen, silicon, and metals, which can 
severely damage economic activities, such as fishing and tourism [4,5]. Moreover, the introduction and accumulation of heavy metals and organic substances (Polycyclic Aromatic Hydrocarbons (PAHs), pesticides, drugs) can induce strong pollution problems involving both the water column and sediment. These pollutants can modify or be incorporated in the food chains, damaging the ecosystem and heightening the risk for human health [5]. In particular, in the past few decades the marine biogeochemical cycle of carbon has undergone an acceleration as a consequence of increased atmospheric $\mathrm{CO}_{2}$, which has resulted in reduced seawater $\mathrm{pH}$ and carbon sinking rates [6].

The alterations in the marine biogeochemical cycles of elements and pollution due to human activities can affect the water column, the bottom sediment, and the transfer processes at the sediment-water interface. The research into and the development of devices to enhance the study of marine biogeochemical and benthic-pelagic coupling processes is therefore very useful [7-9], also in Italy [10-13].

A variety of devices have been developed to study benthic-pelagic coupling processes. In the past few decades, benthic landers with different setups have been developed for a wide range of purposes and their technological features and models have extensively been reviewed [14-22]. Benthic landers are equipped with diverse sensors and devices according to the tasks they are deployed to perform, including microprofilers, planar optodes, and digital cameras to study sediment-water interface properties; eddy correlation systems to measure the fluxes of dissolved chemical species in extensive areas; video cameras to investigate the deep sea biota; and oceanographic sensors $\left(\mathrm{O}_{2}, \mathrm{pH}\right.$, redox potential (Eh or ORP), optical turbidity, CTD, current meters, sediment traps) to study the water column $[8,9,23-28]$. In the past few years, other and much more complex and expensive devices have also been developed, such as landers for hadal environments [29-33], for multipurpose uses, and for transporting other mobile devices [34-37].

An important benthic-pelagic coupling process is the flux of dissolved chemical species at the sediment-water interface, generated by early diagenesis processes [38-40] or by volcanic benthic exhalation [41,42]. Such fluxes can strongly affect the chemistry of the water column, hence its ecology. This is especially true of shelf and coastal environments, where the high intensity of early diagenesis processes, due to a high reactive organic matter content in surface sediments, produces strong fluxes that affect shallow water columns [43].

The benthic fluxes of dissolved substances can be studied by onboard incubation or by in situ experiments, which are usually more reliable [44]. Fluxes are measured in benthic chambers handled by divers [45] in shallow waters, or mounted on benthic landers in deeper waters [44].

Landers equipped with one or more benthic chambers have been developed in the past [46-55].

Two new, low-cost, light, and easy to handle devices, the Amerigo Lander and the Automatic Benthic Chamber (CBA), which have recently been devised to study benthic ecosystems, particularly the fluxes of dissolved substance between sediment and the water column, are illustrated in this paper [56]. The two devices can also be employed jointly to improve the reliability of particular investigations.

The Amerigo Lander is basically a vector that can be deployed in shallow and deep bottoms and which returns to the surface at the end of its mission. It can carry a variety of instruments to study the water column and the benthic ecosystems by measuring various environmental parameters and processes.

The Amerigo Lander and the CBA have provided the Italian scientific community with new and highly innovative instruments to investigate the benthic ecosystems and their interactions with the water column, bridging a scientific and technological gap with North American [25,35,37,46-55], Northern European $[23,24,26,36,49]$ and Asian $[27-30,33,34,50]$ countries.

Their technical features make the two devices versatile and easy to use. The modularity of the lander, the various instruments that it can carry, and the much larger number of parameters that it can measure, compared with existing devices, make it a complete and original apparatus, suitable for operating both in shallows and at great depths. The most innovative features of the CBA are the larger 
area where measurements are acquired, which makes the fluxes more representative $[23,24]$, and its easy and fast rigging, light weight, and maneuverability, which make it easy to use.

Both devices operate autonomously. Amerigo can work from shallow bottoms to depths of $6000 \mathrm{~m}$, whereas the CBA has been designed for shallow water to shelf environments (up to about $200 \mathrm{~m}$ ). Furthermore, the CBA can fit in the Amerigo, if required by research needs.

\section{Amerigo Lander and Automatic Benthic Chamber: Technical Specifications and Equipment}

\subsection{The Amerigo Lander}

The Amerigo Lander is essentially a carrier with a tripod structure that can host different types of instrumentation to measure biogeochemical and geophysical parameters and can collect water and sediment samples (Figure 1). It has been conceived as a simple, low-cost, and practical device that can be employed frequently in a variety of research tasks and environments, since it does not require huge resources, large vessels, or long missions.

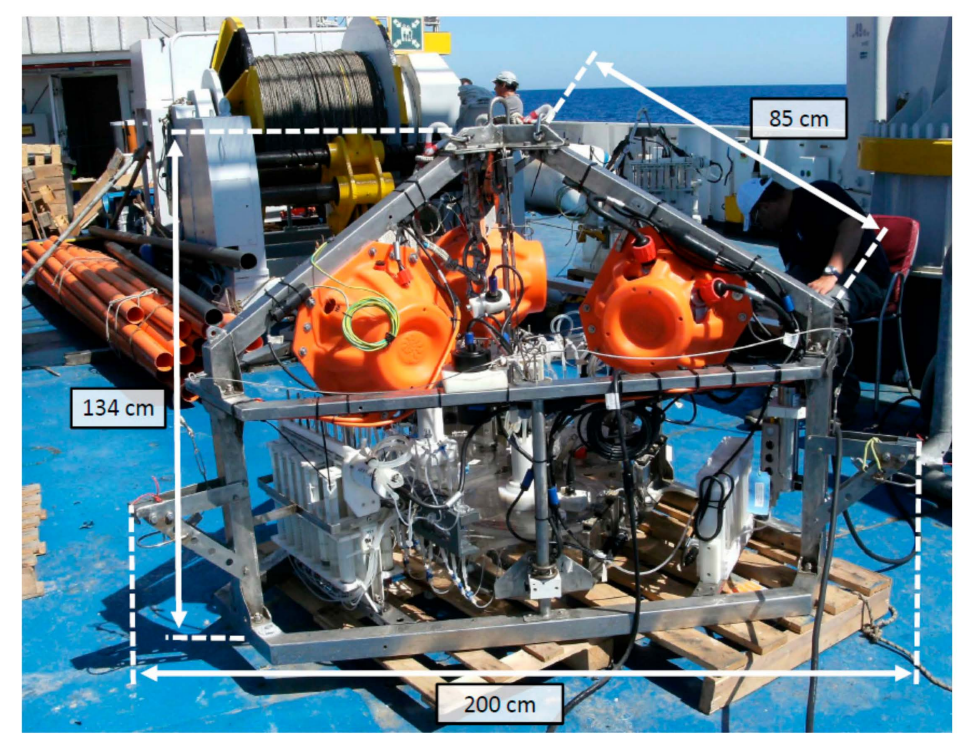

Figure 1. Photograph of the Amerigo Lander showing the tripod structure, the measurements, and the main instrumentation and devices.

Since it reaches the bottom through a speed-controlled free-fall and returns to the surface by positive buoyancy, after a timed release of the ballast weights, it requires no drive or propulsion systems, such as thrusters or cables, nor divers for positioning and recovery. It is also completely automatic, because all hosted instruments and mechanical devices are powered in situ and activated and managed by electronics and software, again without the need for divers or cables. Obviating the need for divers also allows for overcoming stringent safety issues, particularly Italian safety regulations, with considerable savings. The elimination of a cable connection to the vessel makes the lander easy to handle, because the support ship can move while the lander is working on the seafloor.

Another important advantage is its modular structure. In fact, the basic tripod structure can support a variety of components and instrumentation, which can be assembled and set to meet diverse research needs and environmental situations, ensuring flexible and simple operability. In particular, the lander's electronics and power supply have been developed to enable management of additional devices and operations and for increased deployment time. Its modular structure allows the Amerigo Lander to operate in shallow waters (lagoons, estuaries, continental shelves) and deep-bottoms (abyssal plains). Further savings have been obtained from the electronic housings and the release mechanisms.

The lander's basic structure consists of a stainless-steel tripod measuring $200 \mathrm{~cm}$ in width and $134 \mathrm{~cm}$ in height (Figure 1). All the electronic and mechanical devices required for reaching the seabed 
and returning to the surface and for hosting and managing the instruments operating on the seafloor are installed in the tripod (Figure 1).

The bottom is reached by a free fall without the need for thrusters or power, because the descent configuration envisages three ballast weights at the three ends and four buoys (Figure 2), which result in negative buoyancy.

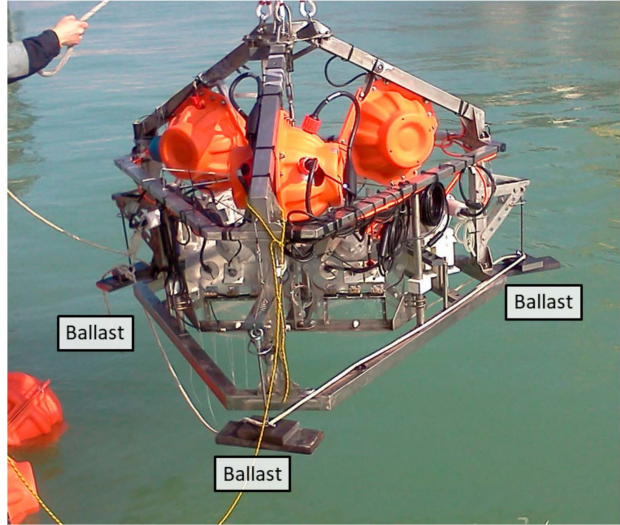

(a)

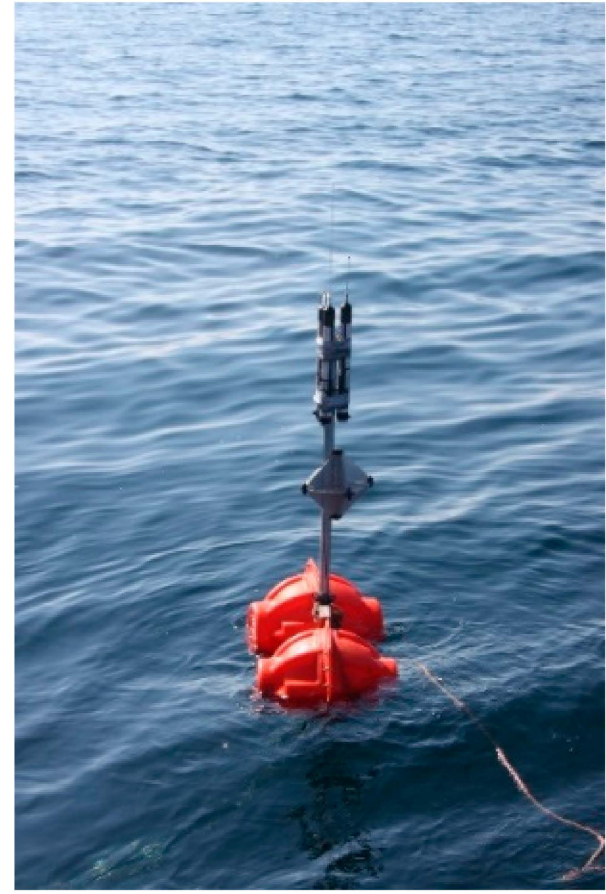

(c)

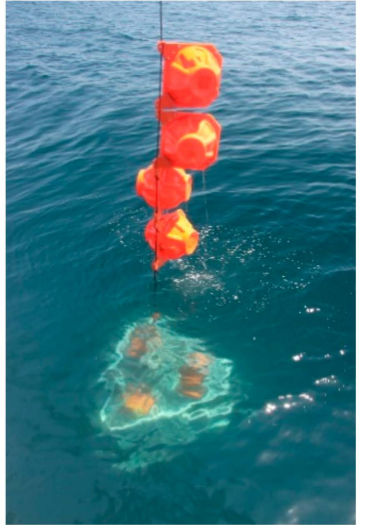

(b)

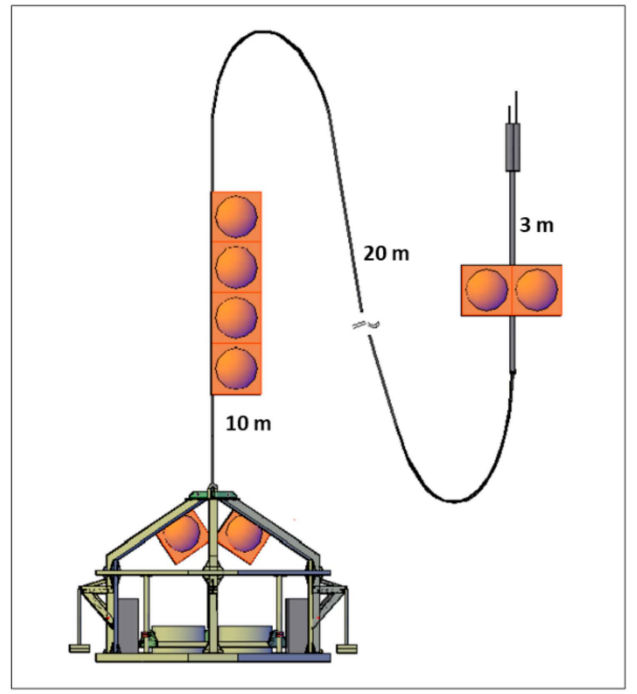

(d)

Figure 2. Amerigo Lander descent configuration. (a) The ballast weights mounted on the tripod; (b) the four buoys tethered to the tripod structure; (c) the recovery pole with the two buoys and the three localization devices; and (d) a schematic drawing of the Amerigo Lander during deployment on the seafloor.

The buoys are commercially available glass spheres (outer diameter $432 \mathrm{~mm}$, thickness $14 \mathrm{~mm}$, buoyancy $260 \mathrm{~N}$ ), built for depths up to $6700 \mathrm{~m}$ (Nautilus Marine Service GMBH, VITROVEX Deep Sea Floatation Sphere), protected by a plastic shell (Nautilus Marine Service GMBH, SR330). The equilibrium between the buoys and the weights depends on the lander's weight in the water, its descent and landing speed, and ascent requirements.

In the present configuration, the lander weighs $294 \mathrm{~kg}$ in air and $131 \mathrm{~kg}$ in water and the 4 buoys have a buoyancy in seawater of $1040 \mathrm{~kg}$, whereas the ballast weighs $45 \mathrm{~kg}$ (15 kg per weight). The buoys 
are tethered to the tripod with a rope $10 \mathrm{~cm}$ in thickness and $5 \mathrm{~m}$ in length (Nautilus Marine Service $\mathrm{GMBH}$, EDDYROPE). Another rope, $10 \mathrm{~cm}$ in thickness, is tied to the recovery pole. The pole is fitted with 2 buoys the same size as the 4 buoyancy array buoys and with a $10 \mathrm{~kg}$ ballast weight, to support the recovery devices about $2 \mathrm{~m}$ above the sea surface (Figure $2 \mathrm{~d}$ ).

With this configuration the lander's initial descent speed is $0.78 \mathrm{~m} / \mathrm{s}$. The thrust of the 2 buoys tied to the recovery pole reduces the descent and landing speed to $0.52 \mathrm{~m} / \mathrm{s}$ (Figure 3). With this set up, the lander can reach the bottom fast enough to avoid being shifted too much by lateral currents, and slowly enough to avoid an excessively strong impact.

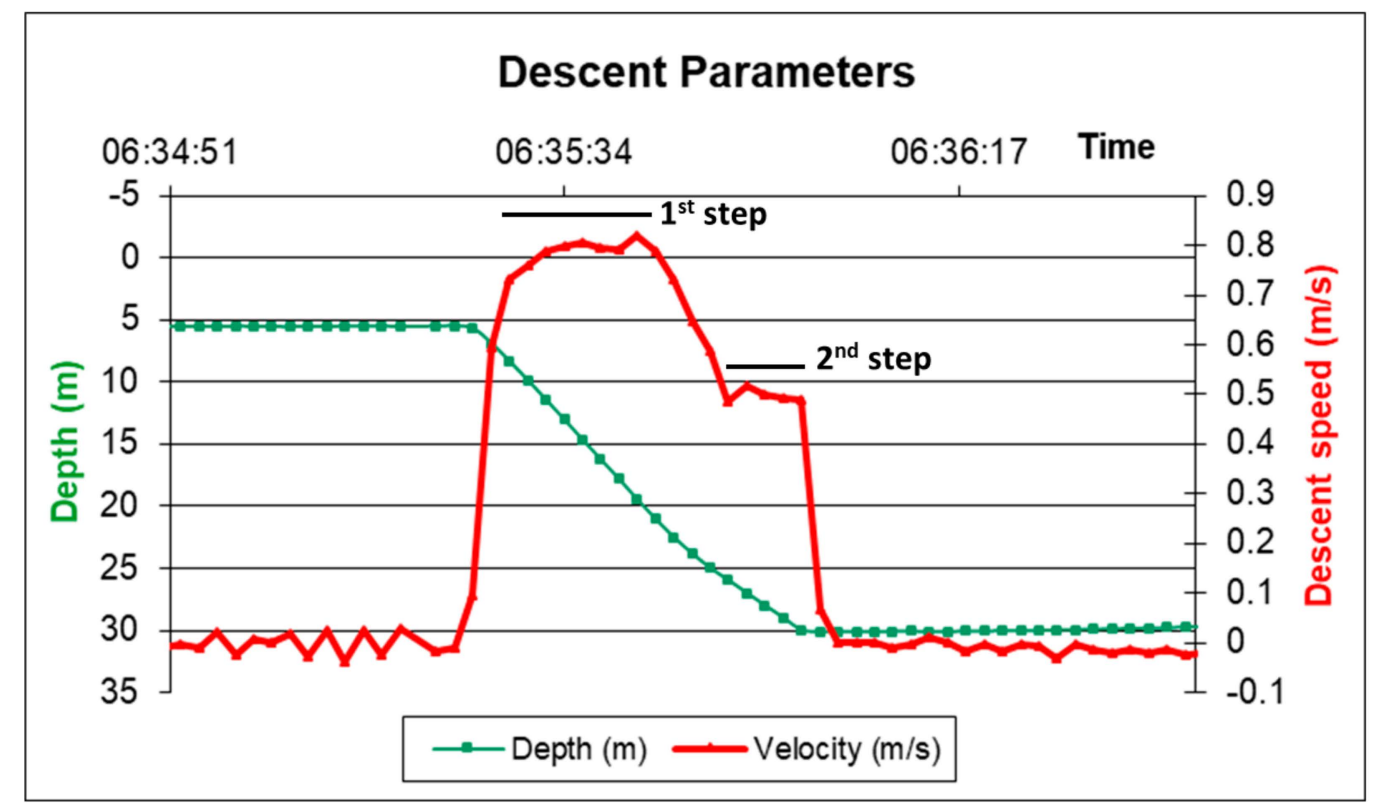

Figure 3. Amerigo Lander descent data. The data refer to the setup with three benthic chambers. Red line: Descent and landing speed. First step: Speed before activation of the first 2-buoy array; Second step: Speed after activation of the two buoys of the recovery pole. Green line: Depth profile.

The buoys are tethered to the tripod by a rope, not mounted directly on the tripod as in several other landers [26,47,50,51,54,55]. This solution has been adopted for two reasons, as follows: (i) As separation of the main tripod structure from the buoys makes the lander lighter and smaller, enhancing maneuverability in deployment and recovery operations, this solution requires smaller frames and less powerful winches; and (ii) this setup allows the lander to be transported in an ordinary van that can be driven with an ordinary license. Furthermore, the buoys and the recovery pole may not be needed in case of operation in shallow water, further enhancing maneuverability and reducing vessel size requirements. These features increase cost-effectiveness and the ease of organization.

After completion of the measurement and sampling operations, the lander returns to the surface autonomously. The release of the three ballast weights and the thrust of the buoy array results in positive buoyancy. In the present configuration ( 4 thrust buoys, 2 recovery pole buoys, 3 benthic chambers) its ascent speed is about $0.2 \mathrm{~m} / \mathrm{s}$ (Figure 4 ).

At the end of the bottom operations, the ballast weights are released by a burn wire mechanism that unlocks the three lever hooks (Figure 5). This system is much less expensive than acoustic release [57] and further contributes to make the lander cost-effective and easy to use and to program. 


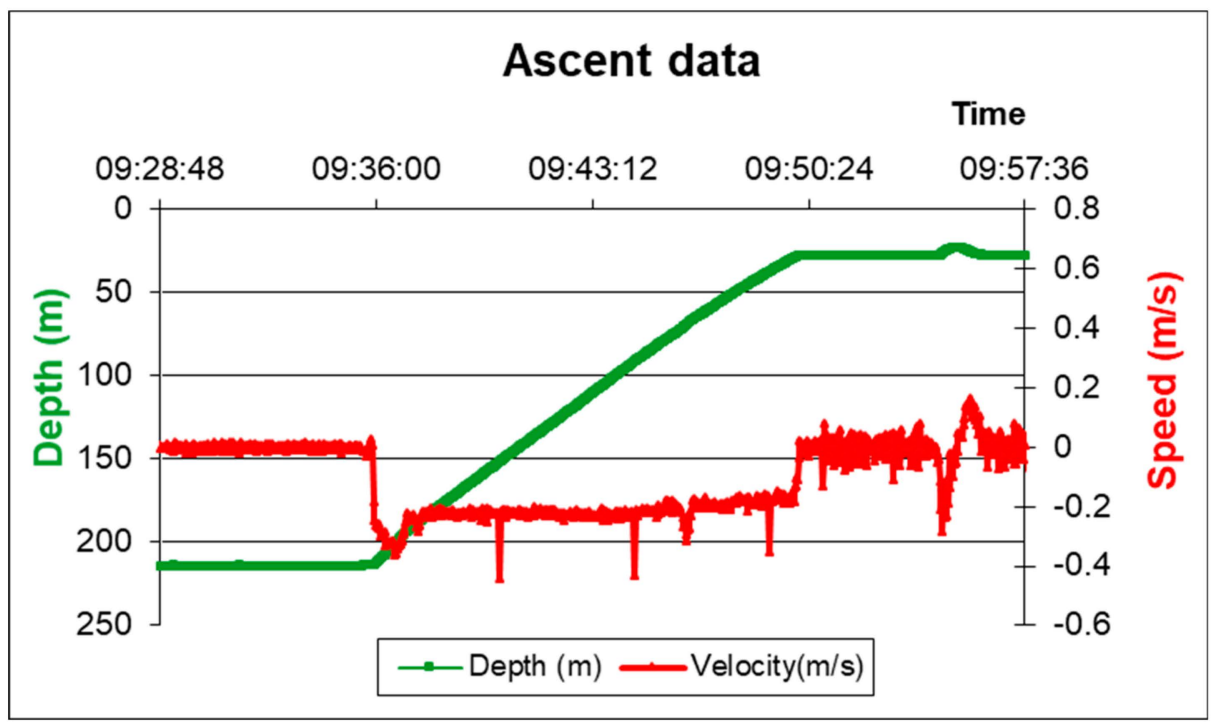

Figure 4. Amerigo Lander ascent data. The data refer to the setup with three benthic chambers. Red line: Ascent speed. Green line: Depth profile.

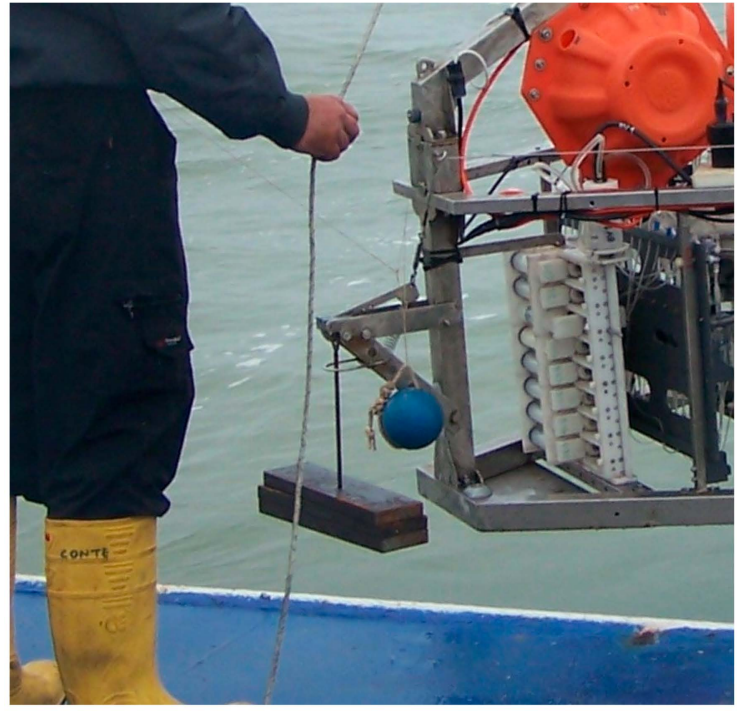

(a)

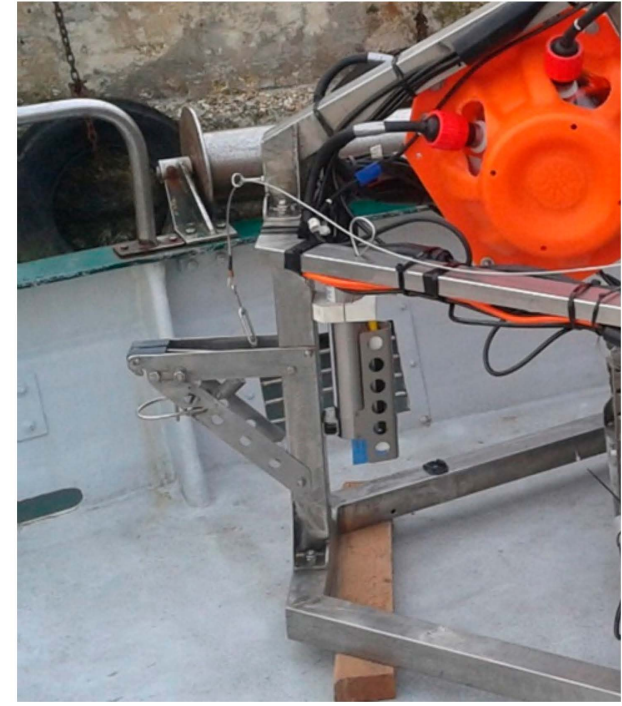

(b)

Figure 5. The three lever hooks in a locked (a) and unlocked (b) position.

In case of deployment in deep water, the Amerigo Lander may surface at a considerable distance from the dropping site, due to lateral sea currents during the ascent. To facilitate recovery, the lander is equipped with three redundant localization devices fitted on the top of the recovery pole, a GPS (Novatech ARGOS Beacons, Dartmouth, NS, Canada), a directional radio (Novatech Radio Beacon, Dartmouth, NS, Canada), and a flash (Novatech Xenon Flasher, Dartmouth, NS, Canada) for night recovery (Figure 6).

The Amerigo Lander is also equipped with instruments for monitoring and measuring the physical-chemical parameters throughout deployment, from descent to ascent. They include a CTD (SBE 37-SI MicroCAT, Sea-Bird Scientific, Bellevue, WA, USA) for continuous water column pressure, conductivity, and temperature recording, and a camera supporting an SD card from 4GB to 32GB (Telesub Lanterna, La Spezia, Italy) (Figure A1, Appendix A) for monitoring the lander's operation. In fact, both instruments monitor the lander's activities, particularly the beginning of descent, the descent speed, the landing, the functioning of the mechanical devices, the beginning and speed of the ascent, and the lander's surfacing. 
Additionally, in this case, both the CTD and the video camera are commercially available to save construction costs. In particular, the video camera is a commercially available camera hosted in a pressure-resistant case.

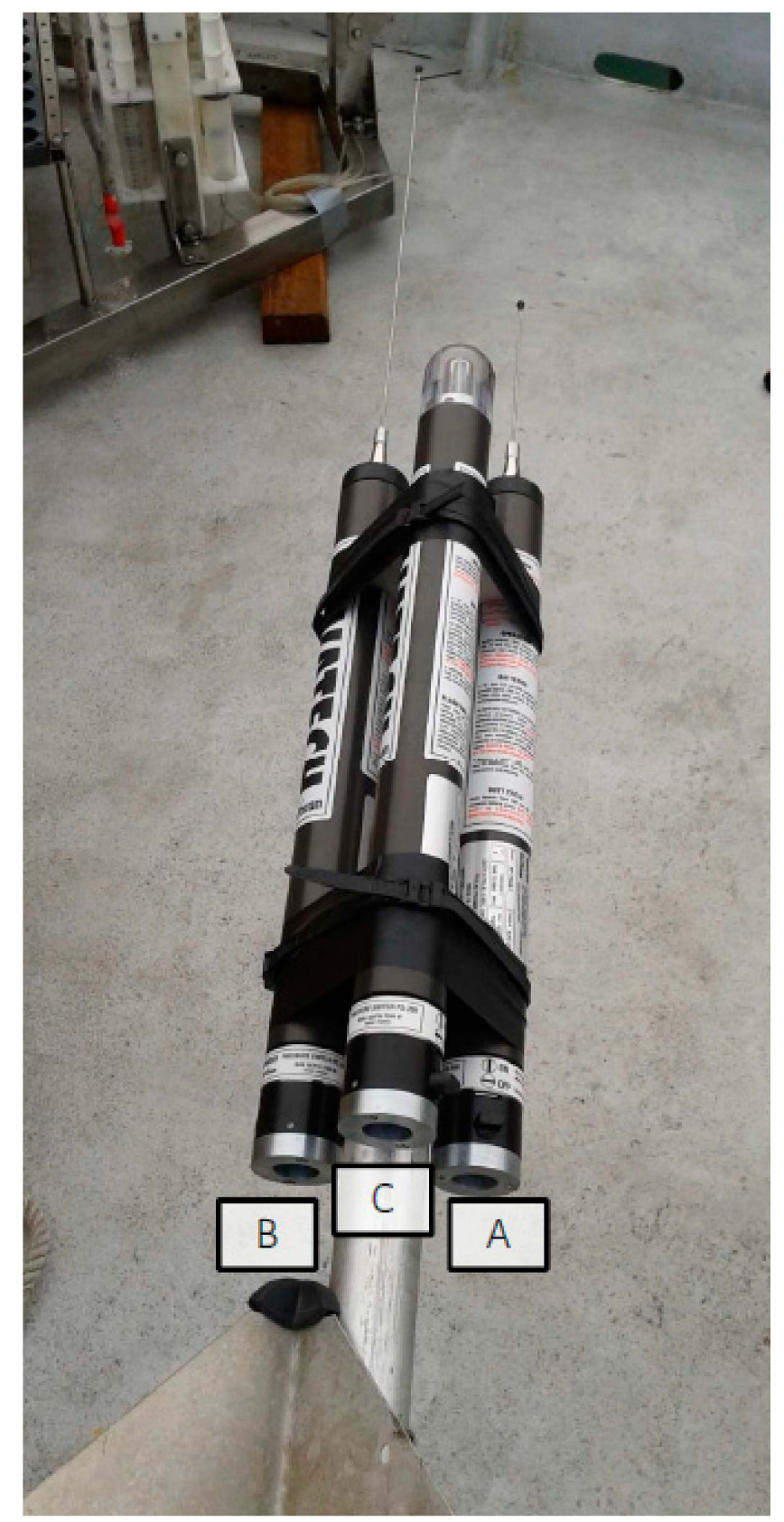

Figure 6. Amerigo Lander recovery system. (A) GPS localization (Novatech ARGOS Beacons); (B) directional radio localization system (Novatech Radio Beacon); and (C) flash for visual localization at night (Novatech Xenon Flasher).

\subsection{Electronics and Power Supply}

The Amerigo Lander's electronics and power supply are developed in-house (Figure 7, Figure A2 of Appendix A). The system is available on request. The burn wire system and all the mechanical and electronic devices, sensors, and probes are powered, turned on, turned off, and managed by the electronics and the batteries fitted in the tripod. The data collected in situ are also stored in the Amerigo electronics. The main hardware components are configured as illustrated in Tables A1 and A2, and Figure A2 of Appendix A. The philosophy of electronics is to be as open as possible, i.e., to enable 
fitting other sensors or devices by the availability of redundant on/off, serial, and analogic ports and the possibility of managing these sensors/devices and other operations by the software.

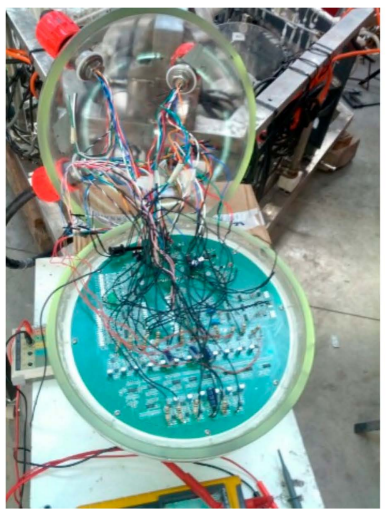

(a)

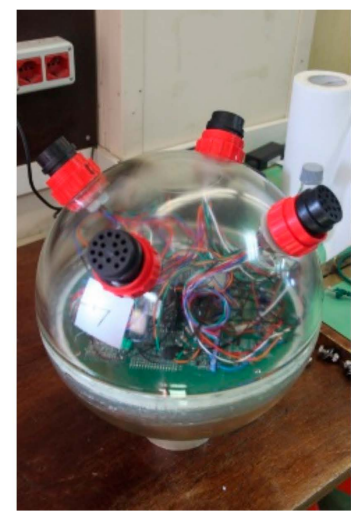

(b)

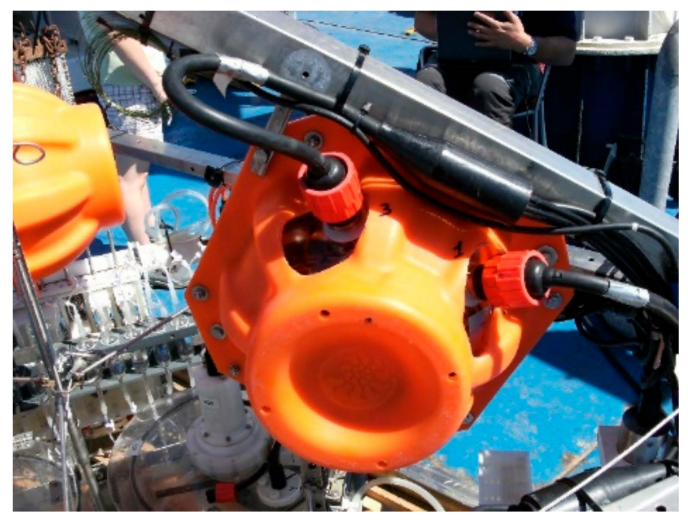

(c)

Figure 7. Amerigo Lander electronics: (a) Firmware testing phase and soldered cables inside the glass sphere; (b) electronics fitted in the glass sphere; (c) a glass sphere mounted on the tripod with the plastic case, marine connectors, and cables.

The Amerigo Lander is powered by two pairs of $12 \mathrm{~V}, 18 \mathrm{Ah}$, rechargeable lead batteries that are connected in parallel and fitted in a pressure-resistant case. The fact that they are commercially available and $\mathrm{Pb}$-based involves lower managing and setup costs, compared to other metal-based batteries. The first pair is supported by the redundant second pair, which is only activated in case of exhaustion or failure of the first pair. This power supply supports about a $40 \mathrm{~h}$ operation of the lander in its present configuration. The $\mathrm{Pb}$ batteries can be increased or their type changed to support different configurations or to extend the operating time.

In the event of a failure of the general power supply or of the main electronics, a safety burn wire device powered by an independent $9 \mathrm{~V}$ battery and controlled by a dedicated electronic circuit is activated, after a predetermined time, to release the ballast for the final ascent. An additional safety system consists of a magnesium ring that is corroded by seawater. In case of the failure of all the electronic devices, its disappearance releases the ballast weights [58].

The electronics and the batteries are hosted in glass spheres built for depths of up to $7000 \mathrm{~m}$ (Nautilus Marine Service GMBH, VITROVEX Deep Sea Instrument Sphere; size: 13", outer/inner diameter: 330/306 mm, glass type: DURAN 8330), which are connected to the electronic devices, sensors, probes, and thrusters by marine connectors (Figure 7). The glass spheres are also commercially available and cost less than metal cylinders.

The two battery pairs are recharged on board by a cable that is removed before deployment. The cable is also used for serial port communication with the PC.

The main serial port (RS232-1) is devoted to communication with the PC. It allows for entering commands, changing the setup, downloading recorded data from the RAM flash memory or, in case of direct monitoring, it enables visualizing the data, the situation on the bottom, and the ongoing operations, as well as reporting malfunction alarms in real time (Figure A2 of Appendix A). The same port can be used to connect an acoustic modem for underwater communication.

The second serial port (RS232-2) is multiplexed in order to communicate with infinite RS-232 serial sensors, limited only by the hardware power connections (Figure A2 of Appendix A).

Different systems have been designed to protect the lander's electronics. The power supply to each electrical device (sensors, motors, batteries, burn wires) is protected by an electrical shunt that limits current drain. In case of failure of a device, the power supply to it is cut off to prevent a general electronic failure. 
Furthermore, the open electronics and the excess of on/off, serial (by means of a multiplexed serial port), and analogic communication ports allows fitting many other electronic sensors, devices, and instruments, with respect to other system that are devised for standardization as well as useful use [28].

The following sensors are currently installed in the Amerigo Lander (Table 1) (Figure A2 of Appendix A):

Table 1. Technical specifications of the sensors installed in the Amerigo Lander.

\begin{tabular}{|c|c|c|c|c|c|}
\hline Sensor Type & Company & Parameter & Resolution & $\begin{array}{c}\text { Initial } \\
\text { Accuracy }\end{array}$ & $\begin{array}{l}\text { Maximum } \\
\text { Depth }(\mathrm{m})\end{array}$ \\
\hline \multirow[t]{3}{*}{ SBE37-SI (CTD) } & \multirow[t]{3}{*}{$\begin{array}{c}\text { Sea Bird } \\
\text { Electronics }\end{array}$} & Conductivity (S/m) & 0.00001 & 0.0003 & 7000 \\
\hline & & Temperature $\left({ }^{\circ} \mathrm{C}\right)$ & 0.002 & 0.0001 & 7000 \\
\hline & & Depth $(\mathrm{m})$ & $0.002 \%$ FS & $0.1 \% \mathrm{FS}$ & 7000 \\
\hline \multirow{3}{*}{$\begin{array}{c}\text { SBE5T (Pump) } \\
\text { Oxygen } \\
\text { Optode } 3830\end{array}$} & $\begin{array}{l}\text { Sea Bird } \\
\text { Electronics }\end{array}$ & & & & 7000 \\
\hline & AANDERAA & $\begin{array}{l}\text { Oxygen concentration } \\
\qquad(\mu \mathrm{M})\end{array}$ & $<1 \mu \mathrm{M}$ & $<8 \mu \mathrm{M}$ & 6000 \\
\hline & & Air saturation (\%) & $0.4 \%$ & $<5 \%$ & 6000 \\
\hline $\begin{array}{c}\text { Seapoint } \\
\text { Turbidity Meter }\end{array}$ & Seapoint & Turbidity (FTU) & $\begin{array}{c}10 \mathrm{mV} / \mathrm{FTU} \\
\text { (range 500 FTU) }\end{array}$ & $<1 \%$ & 6000 \\
\hline Mets & Franatech & Methane & $\begin{array}{c}2.44 \mu \mathrm{M} \\
\text { (range } 50 \mathrm{nM}-10 \mu \mathrm{M} \text { ) }\end{array}$ & $<1 \%$ & 4000 \\
\hline $\mathrm{pH}$ & AMT & $\mathrm{pH}$ & 0.01 & 0.05 & 6000 \\
\hline
\end{tabular}

An important question is the operation limit connected with temperature. The temperature operation limit of Amerigo coincides with the lower operation value between the sensors fitted in the benthic chambers and the polycarbonate (i.e., $40{ }^{\circ} \mathrm{C}$ (optode sensor); if the lander is used without sensors the temperature limit is $<140{ }^{\circ} \mathrm{C}$ (polycarbonate)).

\subsection{Burn Wire Device}

The burn wire mechanism [51] consists of a metal wire coated with a plastic film that is corroded and then broken by an electric current at a bare point where the coating is interrupted (Figure A2, Appendix A). A simple $12 \mathrm{~kg}$ fishing wire coated with a thermo-shrinkable tube is a typical design. The plastic-coated wire usually keeps a lever hook locked. When the electric current runs through the wire, the bare point interacts with seawater, which triggers a reaction (1) that consumes the wire completely, leading to release of the lever hook, as follows:

$$
M_{\text {solid }}^{0}=M_{\text {solute }}^{2+}+2 e^{-},
$$

where $M^{0}$ is the metal of the wire, $2 e^{-}$is the electric current, and $M^{2+}$ is the metal in the solution. The electric circuit is closed by an electric mass on the metal tripod. By this method, any spring- or gravity-based mechanical device can be actioned by the release of a mechanical device or lever hook that can hold several tens of kilos, depending on the length of the lever (Figure 5). A metal wire, $0.4 \mathrm{~mm}$ in thickness with a resistance of a $12 \Omega / \mathrm{m}$, exposed to an electric current of $200 \mathrm{~mA}$ in normal seawater (36 PSU) is usually consumed and broken in about $20 \mathrm{~s}$. As mentioned above, the burn wire system is much less expensive than any acoustic release system.

\subsection{Current Configuration of the Amerigo Lander}

In its current configuration, the Amerigo Lander is equipped with instruments and sensors for measuring benthic fluxes of dissolved chemical species and for monitoring physical-chemical parameters in the near-bottom sea water column. In particular, the former measurements at the sediment-water interface are performed using three benthic chambers, two water sampling systems, and some sensors fitted in the chambers (Figures 8-12). 


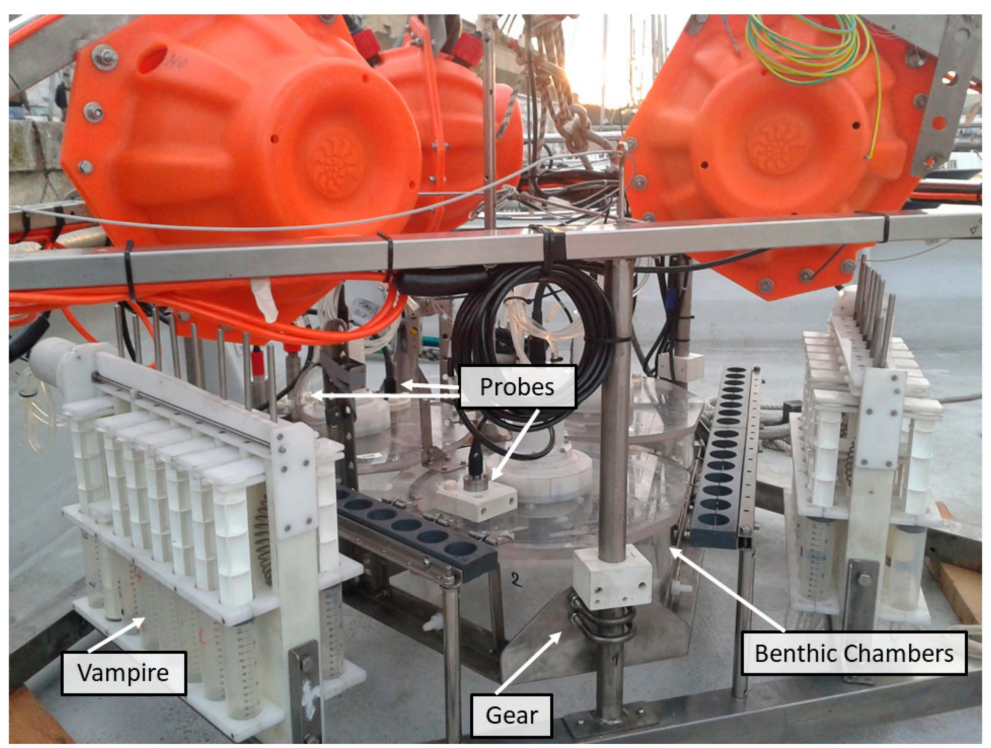

Figure 8. Amerigo Lander: The three benthic chambers, the two water sampling devices, the three probes in a chamber, and the chassis on which the chambers are mounted.

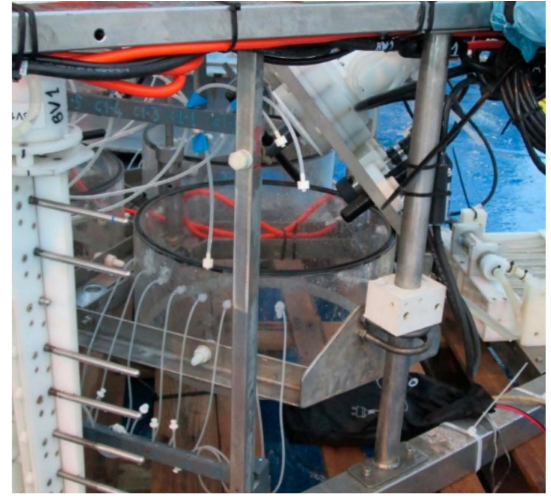

(a)

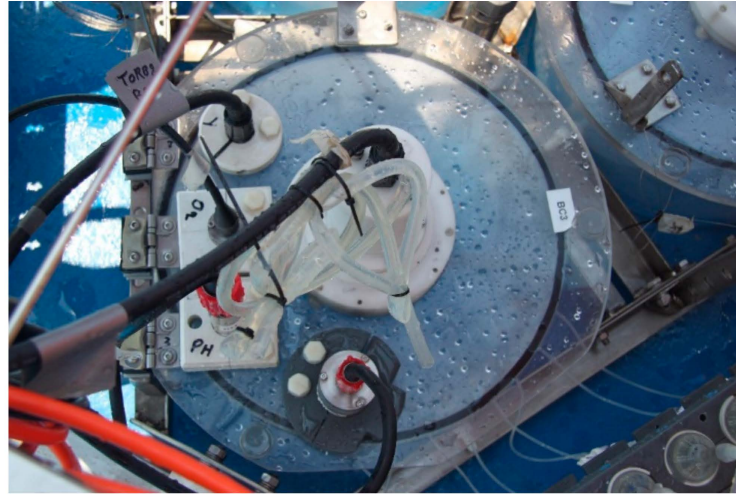

(b)

Figure 9. Amerigo Lander. (a) Lateral view of a benthic chamber mounted on the chassis with the top lid open, the tubes on the lateral wall to collect water samples, and the rotating paddle. (b) Top view of a benthic chamber with the closed top lid fitted with the oxygen, $\mathrm{pH}$, methane, and turbidity sensor.

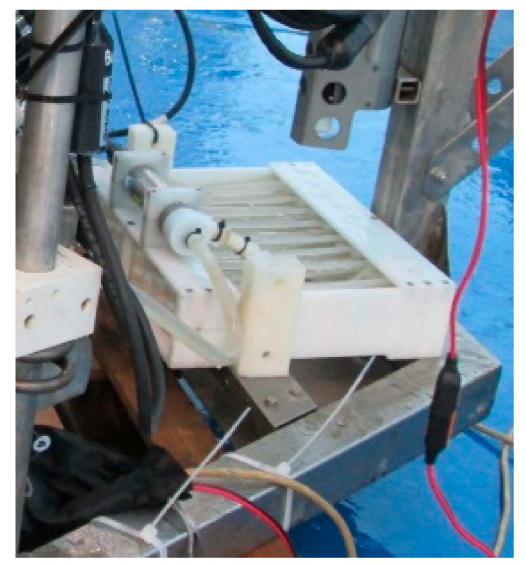

(a)

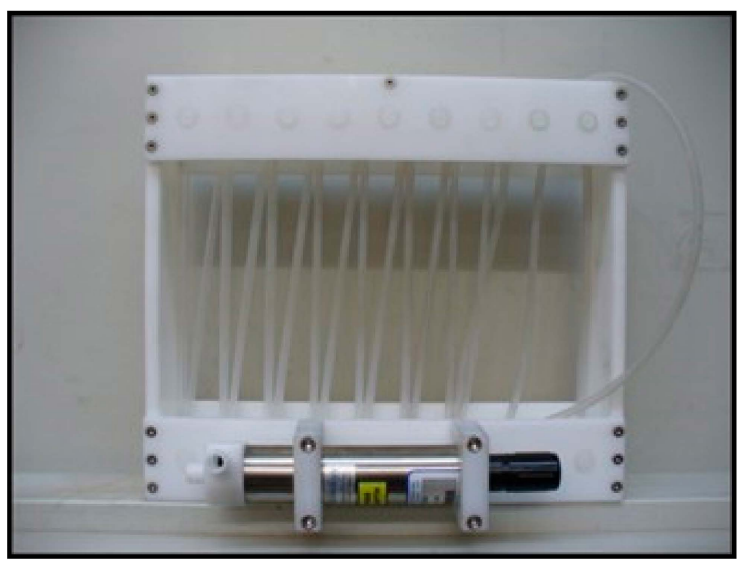

(b)

Figure 10. The OxyStat oxygen replacement device. (a) The pump and the tube connected to the interior of the chamber; (b) view from above. 


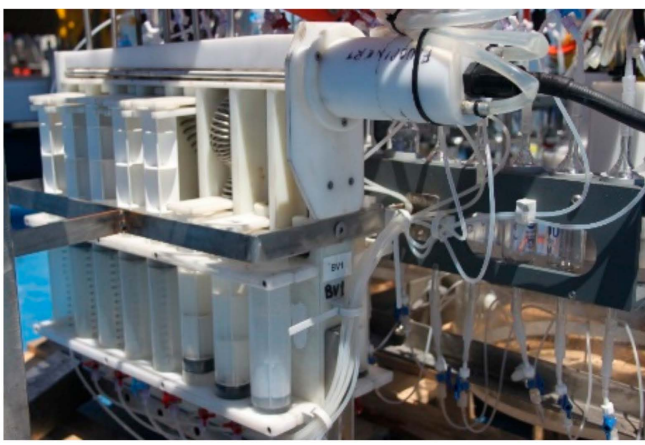

(a)

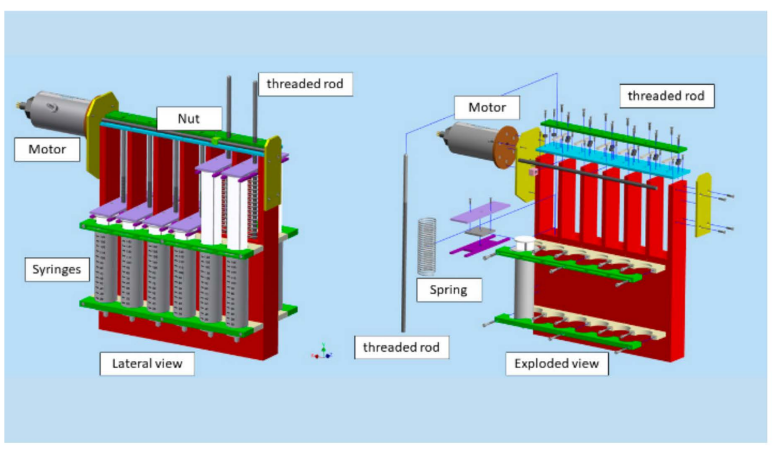

(b)

Figure 11. The VAMPIRE device allows drawing water into the chamber or expelling it as well as injecting a tracer inside the chamber. (a) Photograph of the VAMPIRE device installed on the Amerigo Lander; (b) schematic drawing of the VAMPIRE device.

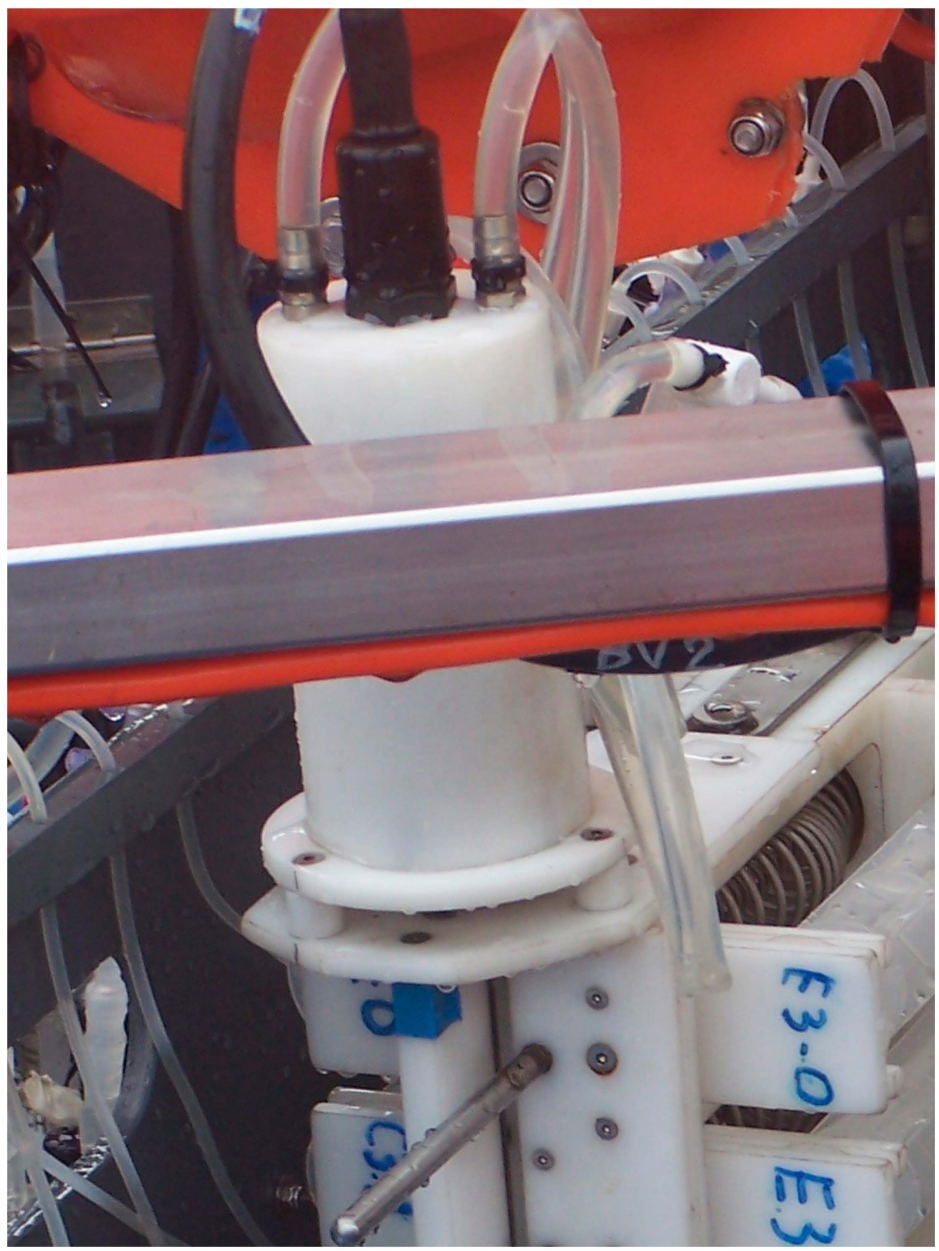

Figure 12. The Delrin case hosting the electric motors with the silicone tube pressure-compensation system.

The benthic chambers are polycarbonate cylinders with a movable polycarbonate top lid (Figures 8 and 9a). The cylinders measure $37 \mathrm{~cm}$ (inner diameter) by $20 \mathrm{~cm}$ (height) and have a countersink in the bottom to facilitate penetration in sediment [46].

The three benthic chambers are mounted on a chassis (Figures 8 and 9a) that is released by a burn wire mechanism a few minutes after the tripod has landed on the seabed. The chambers are mounted $5 \mathrm{~cm}$ over the plate of the structure so that they can penetrate into the sediment for $5 \mathrm{~cm}$, while the remaining $15 \mathrm{~cm}$ remain above the sediment. A few minutes after deployment of the chambers on the seabed, the lid of each chamber is unhooked, again by a burn wire device, thus closing the chamber 
and holding a known volume of water (approximately $17 \mathrm{~L}$ ) overlying a known area of sediment [46]. The chassis and lid release time can be programmed by the lander's software to adapt them to the research task and the type of sea bottom.

The chemical and physical-chemical parameters in the chambers and some solute are measured by the following sensors fitted in each chamber during deployment: An oxygen sensor (AANDERAA, Oxygen Optode 3830, Aanderaa Data Instruments AS, Bergen, Norway), a turbidity sensor (Seapoint Turbidity Meter, Seapoint Sensors, Inc., Exeter, NH, USA), a methane sensor (ASD-Sensortechnik GmbH, METS methane sensor, Franatech Gmbh, Lüneburg, Germany) and a pH (AMT, pH-combined sensor, AMT Analysenmesstechnik GmbH, Rostock, Germany) sensor (Table 1) mounted on the lid (Figure 9b). The power-on/power-off and measurement intervals of each sensor can be set by the lander's software according to research requirements.

The chambers also contain an OxyStat device, which allows for replacing the oxygen consumed in the chamber [59]. The device is connected to the chamber by a water pump (SEABIRD SBE5T, Sea-Bird Scientific, Bellevue, WA, USA) and a silicone tube (Figure 10) and is controlled by the lander's software and the oxygen probe inside the chamber. In practice, the software receives the chamber oxygen concentration data and when its level falls below a given threshold, the software turns the OxyStat pump on. The oxygen-poor water in the chamber is pumped into the $15 \mathrm{~m}$ long gas-permeable silicone tube, it adsorbs oxygen from surrounding seawater, and is pumped back into the benthic chamber. Restoration of the oxygen level to the predetermined threshold results in the pump being turned off. The minimum and maximum oxygen concentrations can be set by the lander's software before the mission or calculated on the basis of the initial concentration measured in the chamber.

Each benthic chamber is connected (Figure 9a) by silicone tubes (inner diameter, $1.5 \mathrm{~mm}$, outer diameter $3 \mathrm{~mm}$ ) to a water sampling device (VAMPIRE) to collect water or to introduce tracers into the chambers (Figure 11). The VAMPIRE consists of a Delrin frame hosting 8 pairs of syringes, each pair capable of collecting/injecting a maximum volume of $280 \mathrm{~mL}$ of water or tracer. If one syringe of the pair is not connected to the inside, seawater outside the chamber can be collected while the other syringe draws water inside the chamber. Each couple of syringes is activated by a nut moving on a rotating stainless-steel rod. The nut moves the levers that release the stainless-steel springs, which actuate the syringe pair in suction or injection mode. The rod is controlled by an electric motor (CBF Motors SRL, CRB35GM, CBF motors srl, Lissone, Italy) which is powered on and off by the lander's software. Its timing and the activation of water sampling or tracer injection can also be set by the lander's software.

In research tasks involving analysis of dissolved gases, a set of glass ampoules can be added before the syringes of the VAMPIRE device (Figure A3, Appendix A) to store the water samples in a gas-impermeable vessel until analysis.

Each benthic chamber is also equipped with a stirring system, consisting of a rotating paddle mounted on the chamber lid (Figure 9a). The paddle is actioned by the coupling of an electric motor (CBF Motors SRL, CRB35GM, CBF motors srl, Lissone, Italy) to a permanent Neodymium magnet (Supermagnete, magnetic disk diameter $30 \mathrm{~mm}$, height $15 \mathrm{~mm}$, Neodymium, N42, nickel-plated, Webcraft $\mathrm{GmbH}$, Gottmadingen, Deutschland). The paddle turns at a speed of 4-6 rpm, reproducing the hydrodynamics near the seabed, which is responsible of the formation of the benthic boundary diffusion layer at the sediment-water interface and, consequently, of the intensity of the benthic fluxes of dissolved chemical species. The motors of the rotating paddles are also activated by the lander's software some minutes after closing of the lid.

Whereas the cases housing the electronics and the batteries are pressure-resistant, those housing the motors actuating the stainless-steel rod of the VAMPIRE device and the rotating paddles of the benthic chambers are pressure-compensated. These cases are Delrin cylinders with two silicone tubes (Figure 12) filled with a non-conductive liquid (commercially available Vaseline oil). If any air bubbles remain in the case, compression of the silicone tubes offsets the pressure difference between inside and outside, avoiding a collapse of the case. 
At the end of each mission, i.e., after completion of the water sampling and sensor measurements in the benthic chambers, the three ballast weights are released by activation of the burn wire device, which induces positive buoyancy. The lander returns to the surface, where it is localized by means of the three positioning devices, and finally recovered on board. Missions typically last 8 to $36 \mathrm{~h}$, depending on the tasks to be performed or the intensity of the benthic fluxes of dissolved substances, and are limited by the power supply, which, at present, supports the systems for about $40 \mathrm{~h}$ (see Section 2.2). However, as noted above, the open philosophy of the electronics allows the increasing of this time.

After the recovery operations, the water samples taken by the syringes are collected from the VAMPIRE, divided and treated in an inert atmosphere (Figure A4, Appendix A) for immediate (on board) or subsequent (laboratory) chemical analysis of the solutes to be determined in the benthic fluxes.

The data collected by the sensors are downloaded into a computer.

The results of the chemical analyses and the data collected by the chemical sensor are then used to calculate the benthic fluxes of dissolved chemical species (see Section 3).

\subsection{Typical Mission of the Amerigo Lander}

The Amerigo Lander hardware is all managed by wizard software, developed in-house. The software helps the operator in setting all the parameters that are required for the lander's function, to activate and test the motors, to monitor all the parameters in real time, to simulate a measurement mission, and to plan the activities for scheduling a mission. The software allows for the downloading and processing of the data collected during the mission and stored in situ. Finally, the software has been developed to fit further sensors and devices and to manage operations that are not currently scheduled.

A typical mission of the Amerigo Lander consists of six sequential phases that need to be correctly planned for the success of the mission, as follows (Figure 13):

1) After the on board programming and checks, such as control of the mooring line and testing of motors, sensors, communication, and security equipment, the lander is immersed into the sea, where it is held at a depth of $5 \mathrm{~m}$, until activation of a dedicated burn wire mechanism releases a small buoy that confirms the functioning of the whole electronic system;

2) Following the buoy check, the lander is released for its free fall to the bottom;

3) After the lander has reached the seabed, a short interval is envisaged to allow the settling of the sediment resuspension, due to the impact of the tripod on the bottom, to settle;

4) Activation of a burn wire mechanism releases the chamber chassis, enabling its settling on the bottom and penetration into sediment for the first $5 \mathrm{~cm}$; all the sensors in the chamber (oxygen, methane, turbidity) and CTD are sampled; the chambers are still open;

5) After another interval, to allow settling of the sediment resuspension due to the impact of the chamber on the bottom and to enable sensor readings, activation of another burn wire releases the benthic chamber lids;

6) Activation of the stirring paddles allows for mixing the seawater in the chambers;

7) The 8 pairs of syringes of the 2 VAMPIRES are activated by user-programmable times;

8) Finally, the ballast weights are released by the last burn wire and the lander floats back to the surface by virtue of its positive buoyancy. 


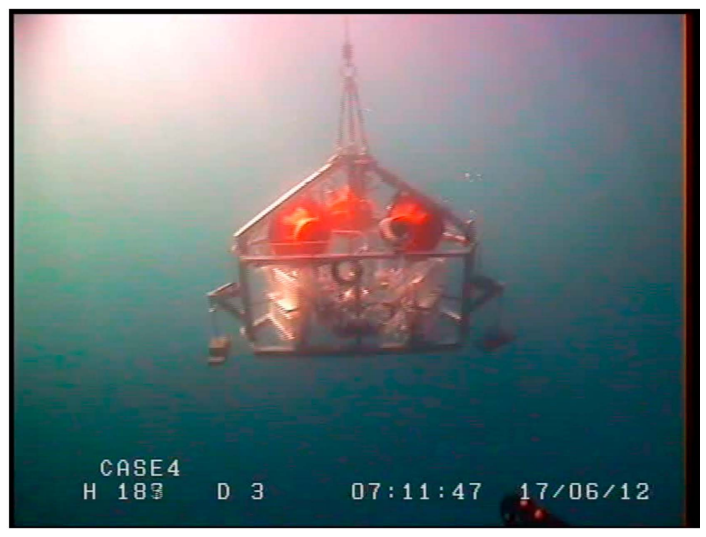

(a)

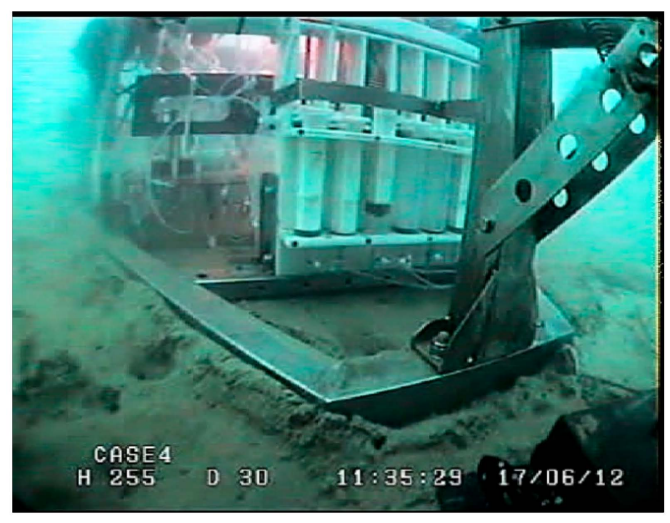

(c)

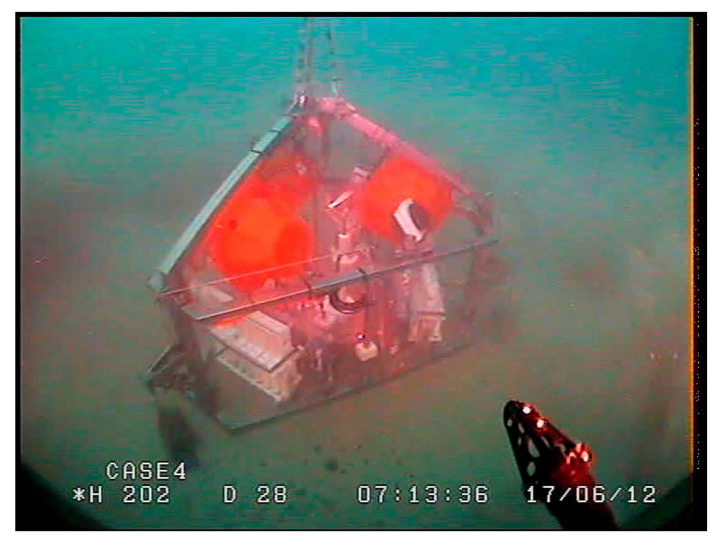

(b)

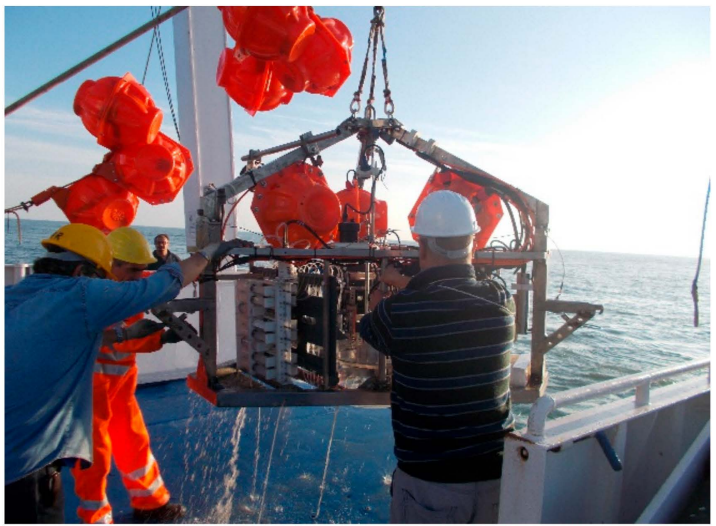

(d)

Figure 13. The Amerigo Lander photographed in some operational phases: (a) In the water before release; (b) on the seabed (view from above); (c) on the seabed (lateral view); and (d) on board after recovery.

\subsection{Other Possible Configurations of the Amerigo Lander}

The basic structure of the lander is the tripod, which is designed to land on the seabed by gravity, counteracted by the positive thrust of the buoys. It then performs its scheduled operations on the seabed and finally returns to the surface by virtue of positive buoyancy, after the release of the ballast weights. All the on-board instruments and devices are built to operate at depths up to $6000 \mathrm{~m}$.

This setup makes the lander a vector that can host different types of instrumentation, such as sensors and probes for monitoring chemical and physical-chemical environmental parameters $(\mathrm{pH}, \mathrm{Eh}$, conductivity, temperature, salinity (calculated), oxygen, methane, $\mathrm{pCO}_{2}, \mathrm{H}_{2} \mathrm{~S}$ ) in the water column during its descent, its permanence on the bottom, and its ascent.

The lander has also been designed to host instruments such as a microprofiler, to study sediment-water interface properties, a penetrometer, to measure the mechanical properties of surface sediments, a gravimeter, to measure seismicity on the seafloor, a corer, to collect sediment cores for early diagenesis, pollution, stratigraphy, or other studies, and passive samplers of water column and sediment solutes, to study pollution and environmental processes and to determine background values. In any case, the open architecture of the electronics allows for fitting other instruments and performing other operations.

Finally, it is a modular device, consisting of the buoy array, the recovery pole, the ballast weights, and the removable and replaceable instruments that perform different tasks in different environments, from very shallow waters, like lagoons and salt marshes, to shelf areas and abyssal planes. 


\subsection{The Automatic Benthic Chamber}

The CBA (Figure 14) has been developed as an alternative to the Amerigo Lander for missions involving measurements in shallow and transitional waters or work that needs to be carried out quickly and economically. This is made possible by the fact that the CBA does not require expensive maintenance, it is practical and fast to fit out, it is light and easy to maneuver, and it is deployed and recovered simply with a rope, which means that it can also be managed by small vessels.

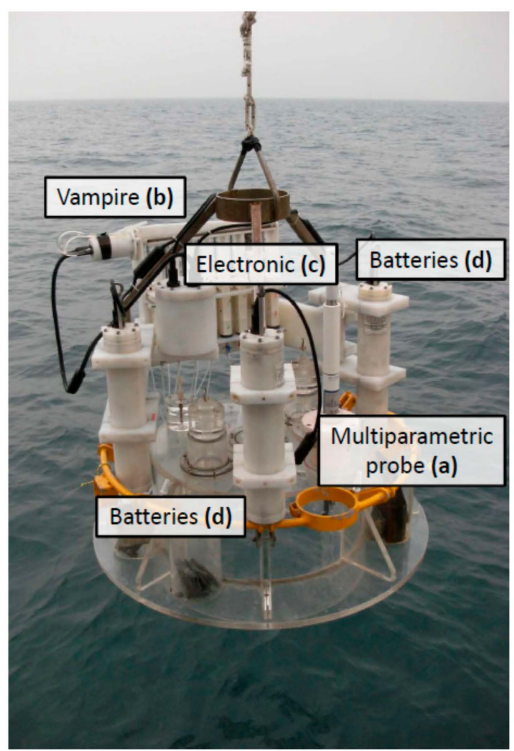

(a)

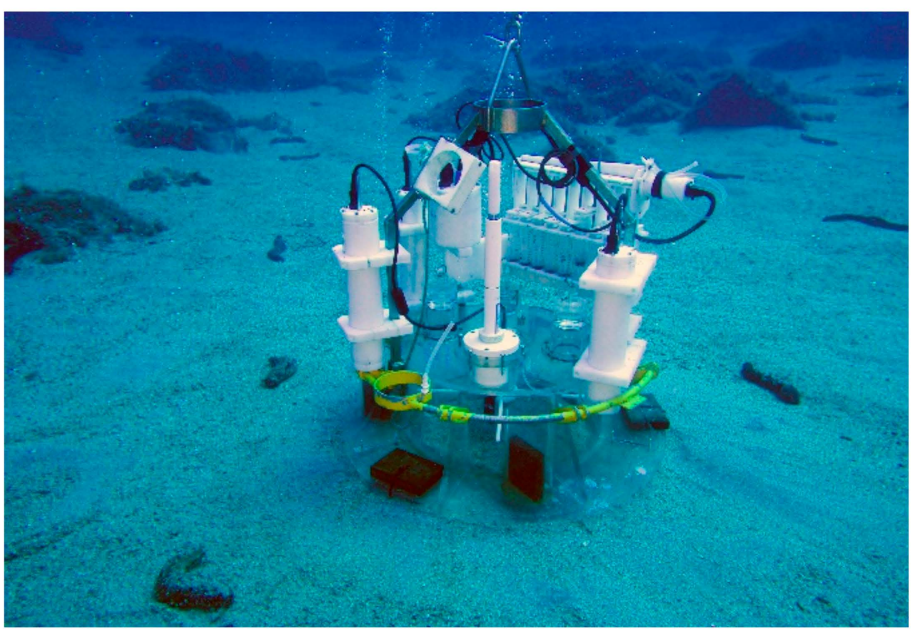

(b)

Figure 14. The Automatic Benthic Chamber during (a) deployment and (b) operational on the seabed with various instruments: Multiparameter probe; VAMPIRE; electronics case; and battery pack cases.

The CBA can also be mounted on the Amerigo Lander, instead of the three benthic chambers, when measurements of benthic fluxes of dissolved chemical species are to be performed over a wider area.

The present CBA is an automated device based on earlier manual benthic chambers managed by divers [60,61]. It is a Plexiglas cylinder open on the bottom and closed on top, which confines a known volume of water (approximately $100 \mathrm{~L}$ ) overlying a known sediment area $\left(3116 \mathrm{~cm}^{2}\right)$ (Figure $\left.14 \mathrm{~b}\right)$. Its inner diameter is $63 \mathrm{~cm}$ and its height is $30 \mathrm{~cm}$, of which $5 \mathrm{~cm}$ penetrate into the sediment and $25 \mathrm{~cm}$ remain above it, due to a lateral horizontal fin (Figure 14). The CBA is fitted with two valves on its top side, to let out the water entering the chamber during descent and landing (Figure 14). Like the Amerigo Lander, the CBA is equipped with an internal stirring system that reproduces the hydrodynamics near the seabed, which is responsible for the formation of the benthic boundary diffusion layer and for the intensity of the dissolved fluxes in the benthic chamber. The stirring system consists of a four-arm rotating paddle fitted on top of the inner side of the chamber. The paddle is actioned by the coupling of an electric motor (CBF Motors SRL, CRB35GM, CBF motors srl, Lissone, Italy) with a Neodymium magnet (Supermagnete, Magnetic disk $30 \mathrm{~mm}$ in diameter, $15 \mathrm{~mm}$ in height, Neodymium, N42, nickel-plated, Webcraft GmbH, Gottmadingen, Deutschland ) and turns at a speed of 4-6 rpm. In the CBA, this motor is activated immediately before deployment by connecting directly the batteries to the motor.

The CBA is also equipped with a multiparameter probe (Hydrolab MS5, OTT HydroMet, Kempten, Germany) for continuous monitoring of temperature, $\mathrm{pH}$, conductivity, dissolved oxygen, Eh, and salinity (calculated) in the chamber (Figure 14). Like the Amerigo Lander, it is also fitted with the VAMPIRE system for collecting water samples inside and outside the chamber and for injecting tracers inside the chamber at programmable times. The motor of the VAMPIRE is activated by simple, easily programmable, and commercially available electronics (Idec MicroSmart FC6A PLC, 
IDEC Corporation, Sunnyvale, CA, USA). The cases housing the electronics, the battery packs, and the motors driving the VAMPIRE and the stirring paddle are made in Delrin and are built to withstand hydrostatic pressure up to a depth of about $200 \mathrm{~m}$. Additionally, in the CBA, the VAMPIRE motor and the electronics cases are pressure-compensated by a silicone tube system filled with a non-conductive liquid (simple Vaseline oil), which affords resistance to high water pressures.

The power supply of the CBA consists of three battery packs (NI-MH size D, $12 \mathrm{~V}, 8 \mathrm{Ah}$, Torricella SRL, Milano, Italy) housed in cylindrical Delrin cases (Figure 14). Two packs are connected directly to the electronics that supply and manage the VAMPIRE motor and one pack is connected directly to the rotating paddle, while the multiparameter probe has its own power supply system.

As regards the planning of CBA operations, the syringe sampling time is set by programming the electronics, while the probe measurement time is programmed by the software of the probe itself.

With regard to deployment and recovery, the CBA is deployed on the seabed and recovered by a rope which, during measurement activities, is attached to and marked by a buoy and a light.

The CBA, both in the standalone configuration and installed in the Amerigo Lander, is a low-cost device that does not require divers or connection cables to the support ship, thus saving the steep cost of divers and the technical problems posed by the connection cable. Further savings are afforded by the fact that the electronics and the batteries are commercially available, hence the low-cost.

Like the Amerigo Lander, the CBA has a temperature operating limit which coincides with the lowest operating value of the sensors fitted in the benthic chamber and the polycarbonate, which is $50{ }^{\circ} \mathrm{C}$ (Hydrolab MS5 Multiprobe). However, if the CBA is used without the multiparameter probe the value is $<140{ }^{\circ} \mathrm{C}$ (polycarbonate).

\section{Benthic Flux Calculation}

The benthic chambers of the Amerigo Lander and the CBA have been designed to measure the release/adsorption of dissolved substances at the sediment-water interface. The principle of their measurement with benthic chambers involves establishing the concentration differences of a solute over time in a known volume, confined over a known area of sediment [62].

Basically, the benthic fluxes of dissolved substances in each benthic chamber of the lander and of the CBA are calculated (2) by dividing the concentration of each solute, measured in the samples collected in the chamber by the syringes-typically nutrients such as ammonium, nitrites, nitrates, phosphates and silica, carbonate species (DIC, alkalinity, $\mathrm{pCO}_{2}$ ), trace elements (heavy metals), and organic pollutants-or recorded by the sensors (oxygen, methane, and $\mathrm{pH}$ ), at the time of the collection or measurement, multiplied by the volume of the benthic chamber and divided by its base area [44].

$$
D i=\frac{\partial C_{i}}{\partial t} V / A,
$$

where $D i$ is the flux of solute $i, C_{i}$ is the concentration of chemical $i, t$ is the time of sample collection or sensor measurement, $V$ and $A$ are the real volume and the area of each benthic chamber.

In practice, the benthic fluxes of each solute are computed as Equation (3) by multiplying the slope of the line, calculated by a least square fit with time (days) on the x-axis and the concentration at different times, multiplied by the height of the benthic chamber, on the y-axis (Figure 15).

$$
D_{i}=y_{i}
$$

where $y_{i}$ is the slope of the time vs. the concentration line of Figure 15. 


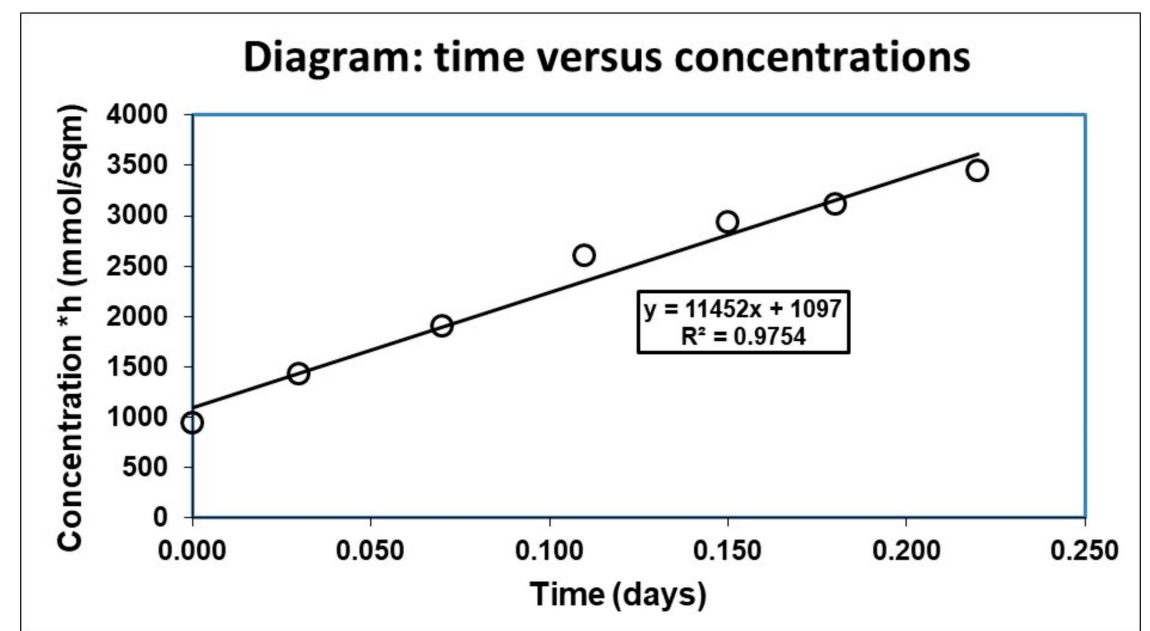

Figure 15. Diagram illustrating the time of water sample collection in the benthic chamber against its concentration and the correlation line.

During deployment, the real volume of each chamber is determined by injecting a solution of a non-reactive solute (tracer), e.g., $\mathrm{CsCl}, \mathrm{BrCl}$ or deionized water, at a known concentration into the chambers [44] and subsequently measuring its concentration in the water samples collected in the syringes as Equation (4).

$$
V_{2}=\frac{V_{1} * C_{1}}{C_{2}}
$$

where $V_{2}$ is the real volume of the benthic chamber, $C_{1}$ is the tracer concentration in the syringe, $V_{1}$ is the volume of the tracer injected into the chamber, and $C_{2}$ is the tracer concentration in the chamber after the injection.

Theoretically, the tracer concentration in the chamber after the initial injection should be constant. If this does not happen, there are three possible explanations, as follows: The benthic chamber is not well placed on the bottom, there are leaks, or an irrigation process is under way in the bottom sediment.

\section{Discussion}

The Amerigo Lander [63-71] and the CBA [41,42,70-77] have successfully been tested and used in measurement and research activities carried out in the framework of international and national projects and in environmental investigations into the impacts of human activities on marine (e.g., harbor sediment dredging) or land environments (e.g., quality of drinking water).

The Amerigo Lander has been tested and employed in shallow, medium, and deep-sea environments, whereas the CBA has been used up to a depth of $140 \mathrm{~m}$.

As a discussion of the data collected by the two devices, we report (Figure 16) the trend of the dissolved oxygen concentrations, measured in the benthic chambers of the lander (by the AANDERAA optode oxygen sensors, Aanderaa Data Instruments AS, Bergen, Norway) and the CBA (by the Hydrolab MS5 oxygen sensor, OTT HydroMet, Kempten, Germany), at the same deployment time and site [71], and on a pelitic and organic matter-rich bottom in front of the Po River Estuary [78,79]. All the benthic chambers of the two devices recorded similar continuously decreasing values, due to mineralization of the high content in fresh reactive organic matter, deposited in front of the Po River Estuary.

The benthic fluxes of solutes, whose concentrations were determined in the water samples collected by the VAMPIRE syringes, also showed reliable data. In fact, very similar values were determined for the fluxes of dissolved inorganic carbon (DIC) (Figure 17) measured by the three benthic chambers of the Amerigo Lander and by the CBA, deployed at the same and site, i.e., on pelitic and fresh organic matter-rich bottom sediments. Furthermore, these DIC flux values are very similar to those measured 
in earlier studies using different benthic chamber devices [80-82] at the same site and in the same season (Figure 17).

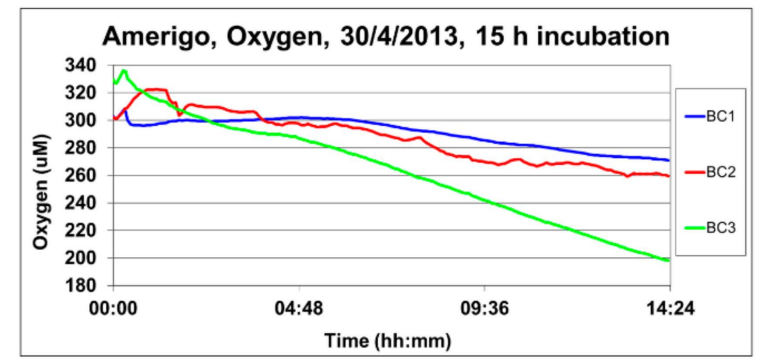

(a)

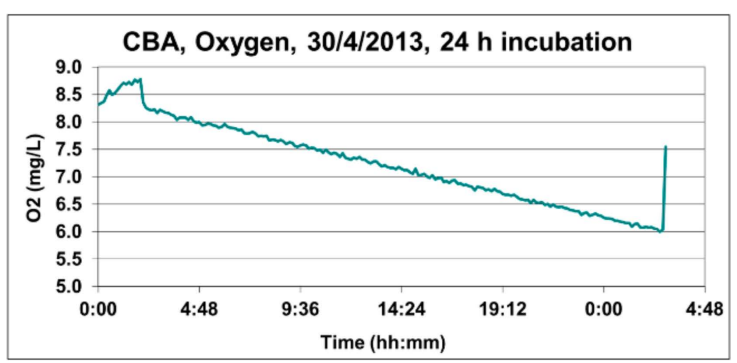

(b)

Figure 16. (a) Oxygen values recorded in the three benthic chambers of the Amerigo Lander $(\mathrm{BC} 1, \mathrm{BC} 2$, BC3) during deployment; (b) oxygen values recorded in the CBA during deployment of the two devices at the same time and site, a mud bottom sediment rich in fresh organic matter (Po River Prodelta).

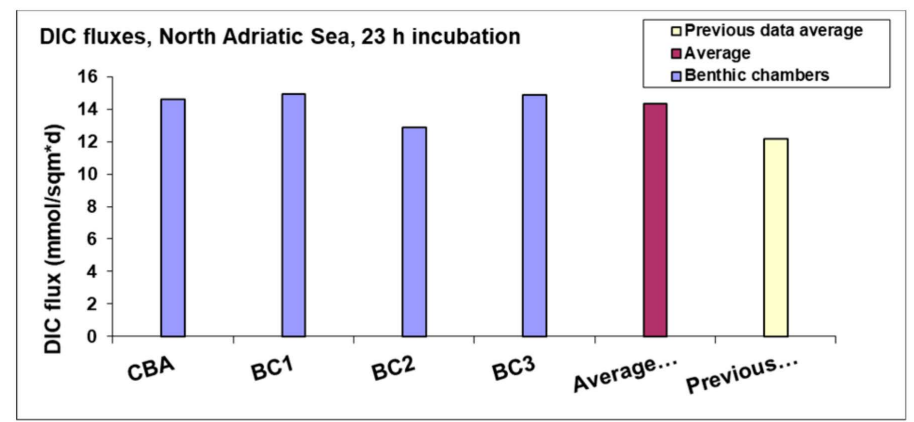

Figure 17. DIC fluxes measured by the CBA, by the Amerigo Lander (BC1, BC2, BC3), and in previous investigations at the same site, a mud bottom sediment rich in fresh organic matter (Po River Prodelta).

On the whole, the oxygen and DIC data reported above (and other solute flux data that are not shown but are available from the authors) demonstrate that the Amerigo Lander and the CBA provide very similar information on benthic fluxes of dissolved substances and that these data are comparable with flux information recorded in previous work conducted at the same site. These first data, therefore, provide very good support for the correct functioning of both our devices.

The Amerigo Lander and the CBA record oxygen concentrations in the different deployment phases. In particular, the oxygen sensors can monitor the oxygen concentrations inside the chambers, the oxygen fluxes at the sediment-water interface can be calculated, and, furthermore, the oxygen trend can be used to check the closing of the benthic chamber.

The trends of the oxygen concentrations recorded in the CBA and in two benthic chambers of the Amerigo Lander (BC1 and $\mathrm{BC} 3$ ) is shown in Figure 18. The data refer to the same time and station, on pelitic bottom sediment in front of the Po River Estuary.

The declining oxygen concentration in the CBA and in the Ox3 chamber, due to benthic respiration or sediment-water interface fluxes, can be appreciated in Figure 18a. Notably, the two peaks in the oxygen concentration trend in the Ox1 chamber of the lander demonstrate that the lid opened twice.

In Figure 18b, the oxygen concentrations were multiplied by the height of the benthic chambers calculated by the dilution of the Cs tracer (4). The oxygen flux was then obtained by the slope of the regression line between time (days) and concentration $\left(\mu \mathrm{mol} / \mathrm{m}^{2}\right)$ (black line, Figure $18 \mathrm{~b}$ ). 


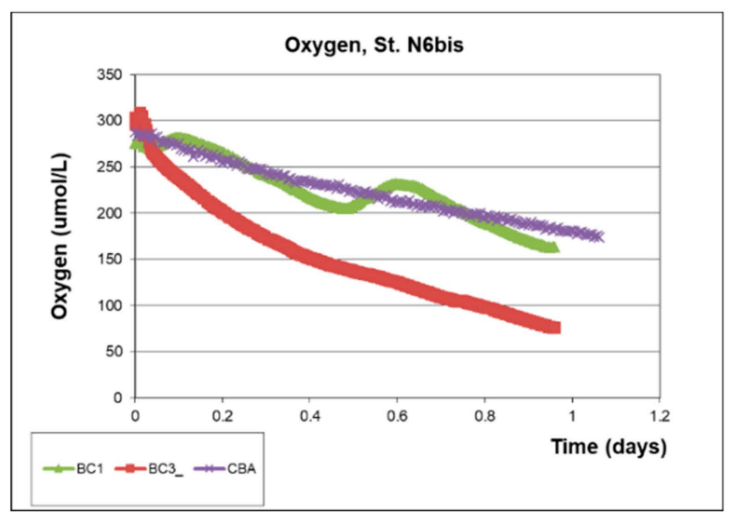

(a)

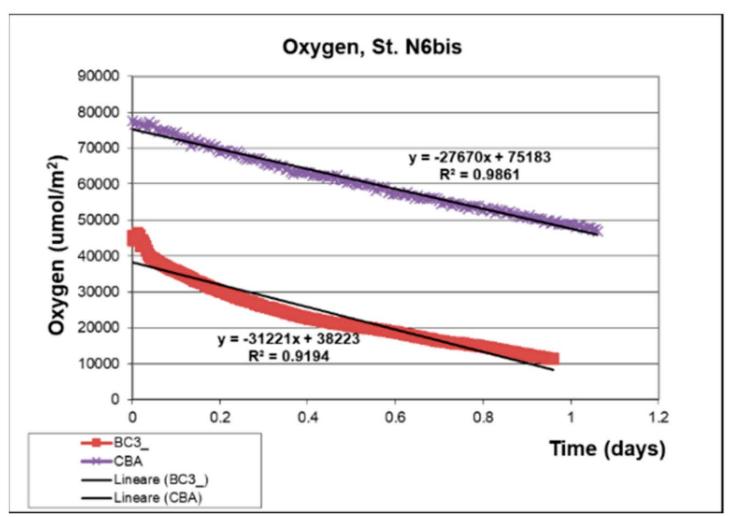

(b)

Figure 18. (a) Oxygen concentrations measured in the CBA and in two benthic chambers (BC1 and BC3) of the Amerigo Lander at the same site, a mud bottom sediment rich in fresh organic matter (Po River Prodelta); (b) multiplication of the oxygen concentrations by the height of the benthic chamber of the $\mathrm{CBA}$ and in $\mathrm{BC} 3$ against time (days) allows calculating the benthic fluxes (slope of the regression line (black line of Figure 18b)).

The fluxes calculated by the slope of the regression line are shown in Figure 19 and Table 2. As demonstrated by the examination of Figure 18, the flux measured in the CBA is almost constant over the $24 \mathrm{~h}$ incubation. For this reason, only the total flux was calculated (Figure 19 and Table 2). In contrast, the oxygen concentration trend in BC3 shows a decreasing flux that can be divided into early (with higher values) and later (with lower values). This is due to the small size of the chamber of the lander, which is more responsive to changes in the environmental conditions inside the chamber, like the reduction in fresh reactive organic matter and oxygen consumption.

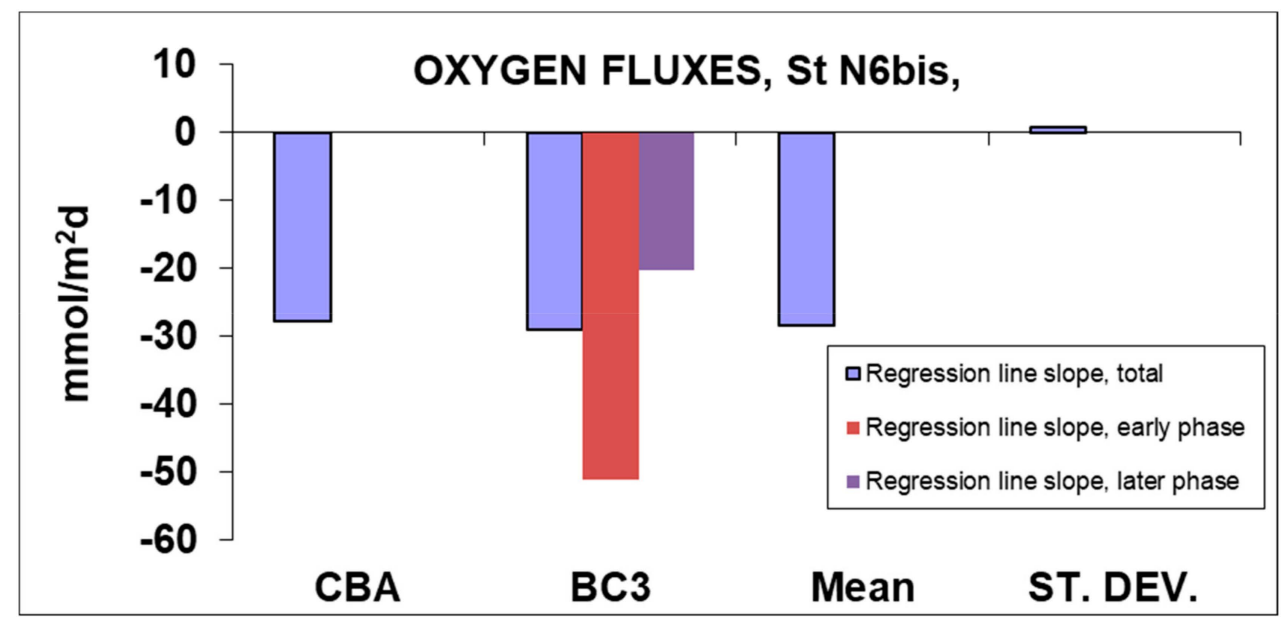

Figure 19. Oxygen fluxes calculated based on the data collected in the CBA and in the BC3 chamber of the Amerigo Lander. Deployment in front of the Po River Prodelta.

The CBA has also been deployed in a volcanic environment, at multiple sites on the seabed around the volcanic complex of Panarea, to measure the dissolved fluxes of DIC and metals released from the bottom in the gas vent area $[39,43,44,54]$. Figure 20 and Table 3 demonstrate the marked difference in DIC fluxes on the bottom between sites affected by vent fluxes (GEOCAL14CBA1, GEOCAL14CBA2, PANA14CBA1, PEG1, SP) and sites devoid of fluxes of dissolved substances at the sediment-water interface (PANA13CBA1, PIANA, 1, 2, 3), due to a surface layer of iron oxyhydroxide [39]. In addition, Figure 20 and Table 3 show very different DIC fluxes on the seafloor around the Panarea volcanic area, which is involved by vent fluxes, and the average DIC benthic fluxes measured in front of the Po River Estuary. 
Table 2. Values of the oxygen fluxes at the sediment-water interface, calculated by the regression of all points (total), the phase with higher slope (early phase) and the lower slope (later phase).

\begin{tabular}{cccc}
\hline$\cdot$ & $\begin{array}{c}\text { Regression Line } \\
\text { Slope, Total }\end{array}$ & $\begin{array}{c}\text { Regression Line Slope, } \\
\text { Early Phase }\end{array}$ & $\begin{array}{c}\text { Regression Line Slope, } \\
\text { Later Phase }\end{array}$ \\
\hline Oxygen & & mmol/m2*days & - \\
\hline CBA & -27.670 & - & -20.144 \\
\hline BC3 & -28.903 & -51.087 & - \\
\hline Mean & -28.287 & - & - \\
\hline ST. DEV. & 0.872 & - & - \\
\hline
\end{tabular}

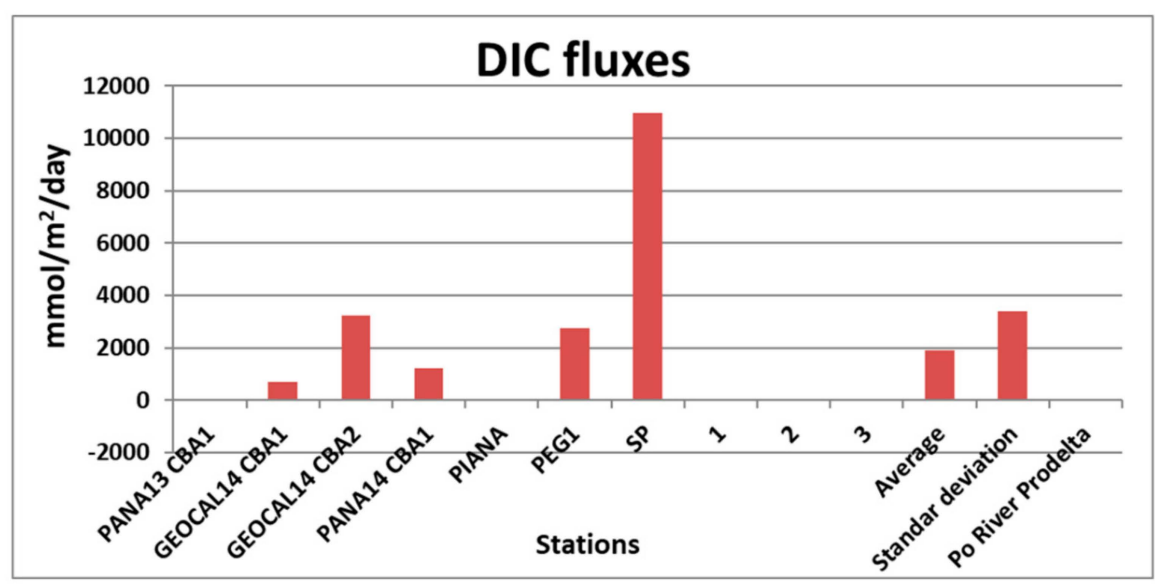

Figure 20. DIC fluxes measured by the CBA in the submarine volcanic area of Panarea and in front of the Po River Prodelta.

Table 3. Values of the DIC fluxes at the sediment-water interface measured by the CBA in the submarine volcanic area of Panarea and in front of the Po River Prodelta.

\begin{tabular}{|c|c|c|}
\hline Cruise & Stations & Flux $\left(\mathrm{mmol} / \mathrm{m}^{2} \cdot \mathrm{d}\right)$ \\
\hline PANA13 & PANA13 CBA1 & 60.60 \\
\hline GEOCAL14 & GEOCAL14 CBA1 & 689.30 \\
\hline GEOCAL14 & GEOCAL14 CBA2 & 3223.90 \\
\hline PANA14 & PANA14 CBA1 & 1212.70 \\
\hline PANA15 & PIANA & -17.99 \\
\hline PANA15 & PEG1 & 2750.60 \\
\hline PANA15 & SP & 10978.00 \\
\hline PANA15B & 1 & 61.54 \\
\hline PANA15B & 2 & -4.41 \\
\hline \multirow[t]{2}{*}{ PANA15B } & 3 & -19.29 \\
\hline & - & - \\
\hline Average & - & 1893.49 \\
\hline Standard deviation & - & 3408.76 \\
\hline Po River Prodelta average & - & 29.00 \\
\hline
\end{tabular}

\section{Conclusions}

The Amerigo Lander and the CBA, two new instruments for measuring the benthic fluxes of dissolved substances, built by the authors, are presented herein. Both devices are autonomous and can 
operate in shelf (CBA) and deep-sea (Amerigo Lander) environments. The Amerigo Lander can also be used for other investigations of shallow and deep benthic ecosystems, because it can carry several different instruments. Both devices have been successfully tested and employed in international and national research projects and in environmental investigations of anthropic impacts by local authorities. These tests and activities have demonstrated the sound performance of the Amerigo Lander and the CBA, as also reflected by the DIC and oxygen data reported above. The CBA has also proved suitable for deployment in a volcanic area affected by gas and fluid vents, for which very few data are available due to technical measurement difficulties. In case of use in volcanic environments, the temperature of the solutes released from the bottom should be carefully monitored because of the temperature operation limits of the sensors $\left(40-50{ }^{\circ} \mathrm{C}\right)$ or of the polycarbonate $\left(140{ }^{\circ} \mathrm{C}\right)$.

Notably, these new instruments mark an important advancement in the Italian marine technology community, providing the means to compete for international research and applicative projects at the same level as foreign institutions.

Author Contributions: The research article has been realized with the following individual contributions. Conceptualization, F.S. and V.M.; methodology, F.S., P.P., G.G., V.M. and L.M.; software, P.P. and F.S.; validation, F.S. and P.P.; formal analysis, F.S. and V.M.; investigation, F.S., P.P. and G.G.; resources, F.S. and V.M.; data curation, F.S., V.M. and P.P.; writing-original draft preparation, F.S. and P.P.; writing-review and editing, F.S. and P.P.; visualization, F.S.; supervision, F.S.; project administration, F.S. and V.M.; funding acquisition, F.S. and V.M.

Funding: Research was funded by the contribution of "Fondo di Ricerca per il Sistema Elettrico nell'ambito, Accordo di Programma RSE S.p.A.-Ministero dello Sviluppo Economico-D.G. Nucleare, Energie rinnovabili ed efficienza energetica".

Acknowledgments: We should thank various people that have contributed in some way to the realization of the Amerigo Lander and of the CBA. In particular, we would to thank Giovanni Ciceri, Enrico Capodarca, Fabio Latini, and Massimo Cocciaretto for the fundamental help in the design phase; Patrizia Giordano, Laura Borgognoni, Massimo Leonetti, Franco Lanini, and Claudio Vannini, as well as the crew and the captains of the N/O Urania Emanuele Gentile and Vincenzo Lubrano Lavadera, and also the dive group of the Black Angels for their contributions in the experimental phases. A special thanks and a particular memory go to the mourned Giovanni Bortoluzzi for the infinite energy that transmitted to all of us.

Conflicts of Interest: The authors declare no conflict of interest. The funders had no role in the design of the study; in the collection, analyses, or interpretation of data; in the writing of the manuscript, or in the decision to publish the results.

\section{Appendix A}

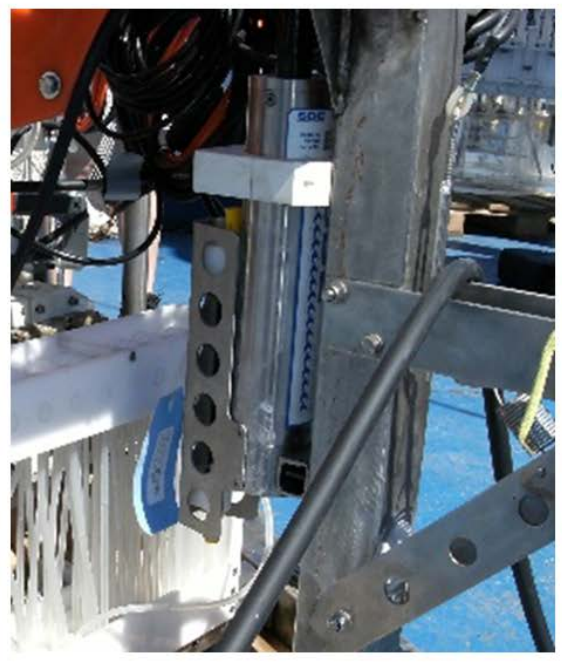

(a)

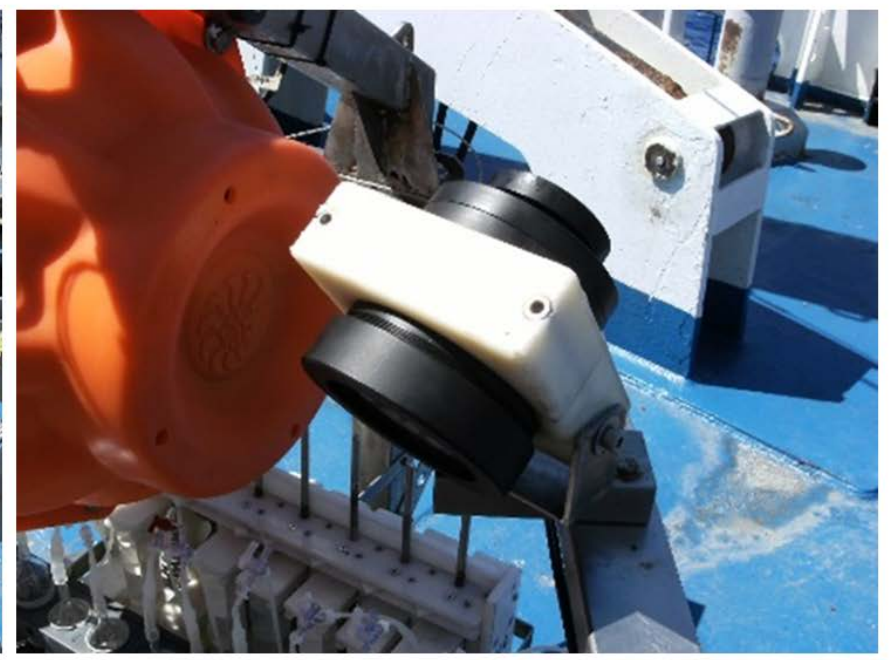

(b)

Figure A1. The Amerigo Lander monitoring instrumentation. (a) The SBE CTD mounted on the Amerigo tripod; (b) the Telesub Lanterna camera installed on the Amerigo Lander. 


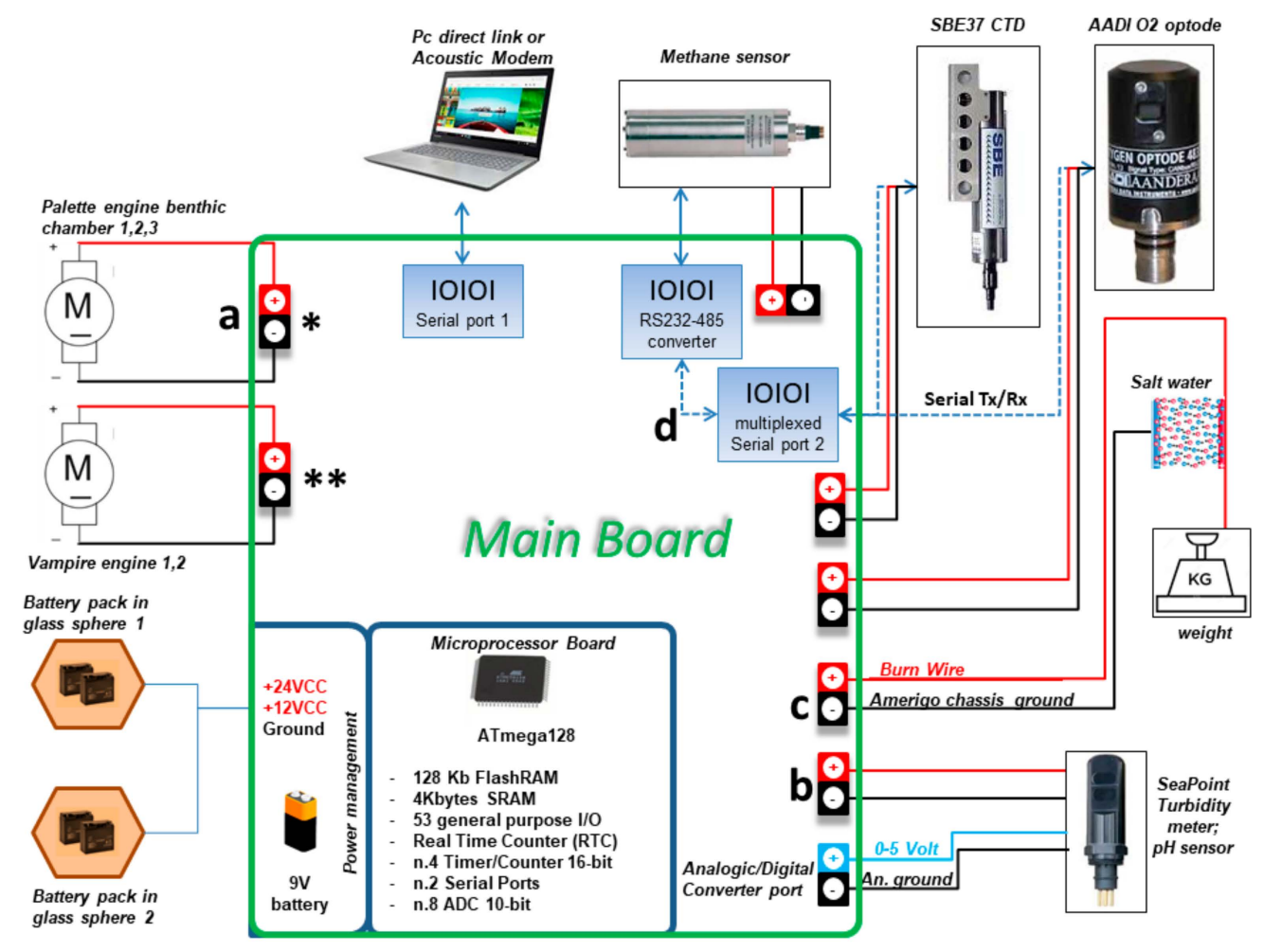

Figure A2. Electronics of the Amerigo Lander: Schematic drawing of the electronics diagram architecture. * Multiplied by three (palettes); ${ }^{* *}$ multiplied by two (VAMPIRE motors); a: dedicated POWER-ON/OFF port ( $\mathrm{H}$ bridge with electronic shunt); b: other " $\mathrm{n}$ " analogic devices; c: other " $\mathrm{n}$ " burn wire systems; $d$ : other " $n$ " digital sensors; blue dashed line: serial Tx/Rx port.

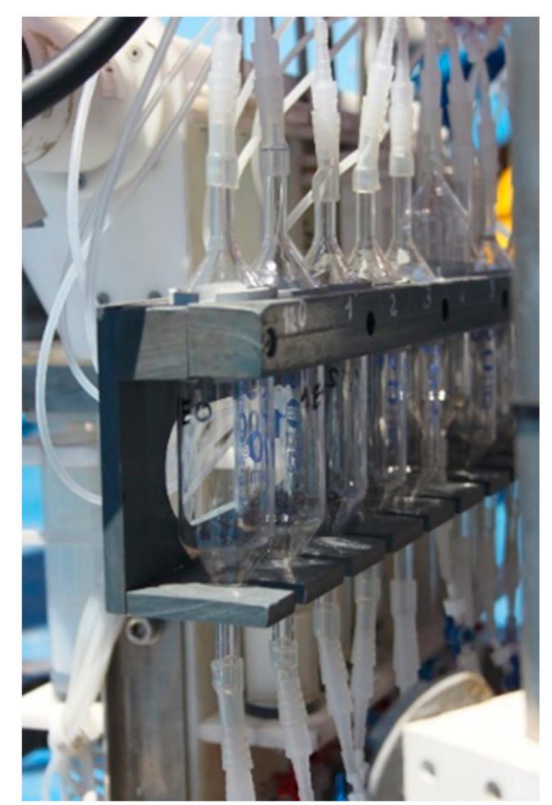

Figure A3. The set of gas-impermeable glass ampoules for water sampling for the analysis of dissolved gases. 


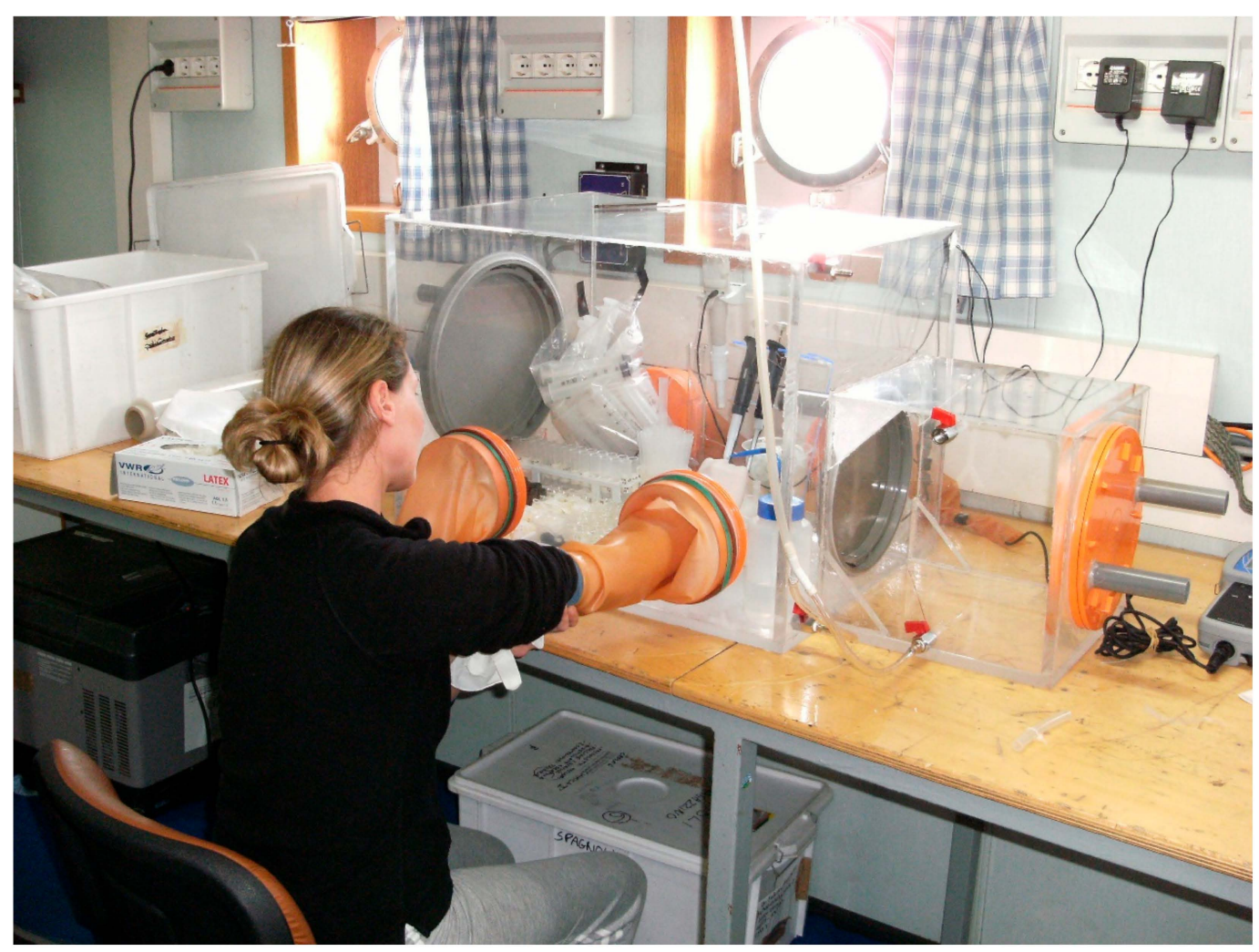

Figure A4. Filtering, subdivision into aliquots, and treatment of the water samples collected by the syringes of the Amerigo Lander is conducted in a Nitrogen glove-box.

Table A1. Main configuration of the Amerigo Lander electronic.

\begin{tabular}{cc}
\hline Type & Description \\
\hline Microprocessor & ATmega128 \\
RAM flash $128 \mathrm{~Kb}$ \\
RAM $4 \mathrm{~Kb}$ \\
e2prom $4 \mathrm{~Kb}$ \\
Internal clock \\
n. 3 timer 16 bit \\
n. 8 ADC channels 10 bit \\
n. 2 TTL serial ports \\
serial flash RAM $4 \mathrm{Mb}$ \\
n. 2 RS232 serial ports \\
n. 3 RS485 ports \\
n. 8 analogic inputs \\
n. 2 digital inputsn. \\
\end{tabular}


Table A2. Configurations of the general inputs and outputs of the electronic of the Amerigo Lander.

\begin{tabular}{|c|c|c|}
\hline Name & Type & Description \\
\hline OUT 1 & ON/OFF & Power terminals for CTD sensor \\
\hline OUT 2 & ON/OFF & Power terminals for $\mathrm{O} 2$ sensor number 1 , chamber n.1 \\
\hline OUT 2 & $\mathrm{ON} / \mathrm{OFF}$ & Power terminals for $\mathrm{O} 2$ sensor number 2 , chamber $n .2$ \\
\hline OUT 4 & ON/OFF & Power terminals for $\mathrm{O} 2$ sensor number 3 , chamber $n .3$ \\
\hline OUT 5 & ON/OFF & Power terminals for $\mathrm{CH} 4$ sensor number 1 , chamber $\mathrm{n} .1$ \\
\hline OUT 6 & ON/OFF & Power terminals for $\mathrm{CH} 4$ sensor number 2 , chamber $\mathrm{n} .2$ \\
\hline OUT 7 & ON/OFF & Power terminals for $\mathrm{CH} 4$ sensor number 3 , chamber n. 3 \\
\hline OUT 8 & ON/OFF & Power terminals for analogic sensors (n.2 turbidity and n.1pH) \\
\hline OUT 9 & ON/OFF & Power terminals - Engine palette chamber n.1 (mixing water) \\
\hline OUT 10 & $\mathrm{ON} / \mathrm{OFF}$ & Power terminals - Engine palette chamber n.2 (mixing water) \\
\hline OUT 11 & $\mathrm{ON} / \mathrm{OFF}$ & Power terminals -Engine palette chamber n.3 (mixing water) \\
\hline OUT 12 & $\mathrm{ON} / \mathrm{OFF}$ & Engine VAMPIRONE number 1 \\
\hline OUT 13 & ON/OFF & Engine VAMPIRONE number 2 \\
\hline OUT 14 & ON/OFF & Burn wire n.1 Buoy electronic check \\
\hline OUT 15 & ON/OFF & Burn wire n.2 Benthic chamber release \\
\hline OUT 16 & ON/OFF & Burn wire n.3 Benthic chamber cover release \\
\hline OUT 17 & $\mathrm{ON} / \mathrm{OFF}$ & Burn wire n.4 Benthic chamber cover release \\
\hline OUT 18 & ON/OFF & Burn wire $\mathrm{n} .5$ weights release \\
\hline OUT 19 & $\mathrm{ON} / \mathrm{OFF}$ & Power terminals 24 Volts for microprofiler \\
\hline OUT 20 & ON/OFF & OxyStat pump \\
\hline RS232 1 & RS232 & Main serial port - PC communication \\
\hline RS232 2-1 & RS232 & CTD \\
\hline RS232 2-2 & RS232 & serial communication with $\mathrm{O} 2$ sensor $n .1$, chamber $n .1$ \\
\hline RS232 2-3 & RS232 & serial communication with $\mathrm{O} 2$ sensor $n .2$, chamber $n .2$ \\
\hline RS232 2-4 & RS232 & serial communication with $\mathrm{O} 2$ sensor $n .3$, chamber $n .3$ \\
\hline RS232 2-5 & RS232 & serial communication with $\mathrm{pH}$ sensor $\mathrm{n} .1$, chamber $n .1$ \\
\hline RS232 2-6 & RS232 & serial communication with $\mathrm{pH}$ sensor $\mathrm{n} .2$, chamber $n .2$ \\
\hline RS232 2-7 & RS232 & serial communication with $\mathrm{pH}$ sensor $\mathrm{n} .3$, chamber $n .3$ \\
\hline RS485 1 & RS485 & serial communication with $\mathrm{CH} 4$ sensor $n .1$, chamber n.1 \\
\hline RS485 2 & RS485 & serial communication with $\mathrm{CH} 4$ sensor $\mathrm{n} .2$, chamber $\mathrm{n} .2$ \\
\hline RS485 3 & RS485 & serial communication with $\mathrm{CH} 4$ sensor n. 3 , chamber n.3 \\
\hline an 1 & analogical in & Analogical (0-5V) Turbidity sensor $n .1$, chamber $n .1$ \\
\hline an 2 & analogical in & Analogical $(0-5 \mathrm{~V})$ Turbidity sensor n. 2, chamber n.2 \\
\hline an 3 & analogical in & Analogical $(0-5 \mathrm{~V})$ Turbidity sensor n. 3, chamber n.3 \\
\hline an 4 & analogical in & NC-future purpose $\left(\mathrm{pCO}_{2}\right)$ \\
\hline an 5 & analogical in & NC-future purpose (Eh) \\
\hline an 6 & analogical in & NC-future purpose $\left(\mathrm{H}_{2} \mathrm{~S}\right)$ \\
\hline an 7 & analogical in & NC-future purpose (other sensor) \\
\hline an 8 & analogical in & NC-future purpose (other sensor) \\
\hline DI 1 & digital IN & magnetic sensor (future purpose, VAMPIRONE position) \\
\hline DI 2 & digital IN & magnetic sensor (future purpose, VAMPIRONE position) \\
\hline
\end{tabular}

\section{References}

1. Douvere, F. The importance of marine spatial planning in advancing ecosystem-based sea use management. Mar. Policy 2008, 32, 762-771. [CrossRef]

2. Pérez-Albaladejo, E.; Rizzi, J.; Fernandes, D.; Lille-Langøy, R.; Goksøyr, A.; Oros, A.; Spagnoli, F.; Porte, C. Assessment of the environmental quality of coastal sediments by using a combination of in vitro bioassays. Mar. Pollut. Bull. 2016, 108, 53-61. [CrossRef] [PubMed]

3. Catalano, G.; Azzaro, M.; Bastianini, M.; Bellucci, L.G.; Bernardi Aubry, F.; Bianchi, F.; Burca, M.; Cantoni, C.; Caruso, G.; Casotti, R.; et al. The carbon budget in the northern Adriatic Sea, a winter case study. J. Geophys. Res. Biogeosci. 2014, 119, 1399-1417. [CrossRef]

4. Legendre, L. Marine Biogeochemical Cycles; John Wiley \& Sons, Inc.: Hoboken, NJ, USA, 2014; pp. $145-187$. 
5. Pörtner, H.-O.; Karl, D.M.; Boyd, P.W.; Cheung, W.W.L.; Lluch-Cota, S.E.; Nojiri, Y.; Schmidt, D.N.; Zavialov, P.O. Ocean systems. In Climate Change 2014: Impacts, Adaptation, and Vulnerability. Part A: Global and Sectoral Aspects. Contribution of Working Group II to the Fifth Assessment Report of the Intergovernmental Panel on Climate Change; Field, C.B., Barros, V.R., Dokken, D.J., Mach, K.J., Mastrandrea, M.D., Bilir, T.E., Chatterjee, M., Ebi, K.L., Estrada, Y.O., Genova, R.C., et al., Eds.; Cambridge University Press: Cambridge, UK, 2014; pp. 411-484.

6. Gattuso, J.P.; Magnan, A.; Billé, R.; Cheung, W.W.; Howes, E.L.; Joos, F.; Allemand, D.; Bopp, L.; Cooley, S.R.; Eakin, C.; et al. Contrasting futures for ocean and society from different anthropogenic $\mathrm{CO}_{2}$ emissions scenarios. Science 2015, 349, aac4722. [CrossRef] [PubMed]

7. Spagnoli, F.; Bergamini, M.C. Water-solid exchanges of nutrients and trace elements during early diagenesis and resuspension of anoxic shelf sediments. Waterair Soil Pollut. 1997, 99, 541-556. [CrossRef]

8. Apitz, S.E.; Bell, E.; Gilbert, F.; Hall, P.; Kershaw, P.; Nickell, L.; Parker, R.; Rabouille, C.; Shimmield, G.; Solan, M.; et al. Coastal Ocean Benthic Observatories (COBO): Integrated tools for the in situ observation and study of benthic ecosystem biogeochemical processes. In Proceedings of the 230th National Meeting of the American-Chemical-Society, Division of Geochemistry, in-situ Methods and Investigations in Environmental Science, Washington, DC, USA, 28 August-1 September 2005.

9. Apitz, S.E.; Bell, E.; Breuer, E.; Damgaard, L.; Gilbert, F.; Glud, R.; Hall, P.; Kershaw, P.; Lansard, B.; Nickell, L.; et al. Integrating new technologies for the study of benthic ecosystem response to human activity: Towards a Coastal Ocean Benthic Observatory (COBO). In Proceedings of the XVIII Congresso dell'Associazione Italiana di Oceanologia e Limnologia (AIOL), Napoli, Italy, 3-7 July 2006; Volume 19, pp. 73-78.

10. Spagnoli, F.; Marcaccio, M.; Frascari, F. Early diagenesis processes and benthic fluxes in different depositional environments of the Northern and Central Adriatic Sea. In Proceedings of the XVIII Congresso dell'Associazione Italiana di Oceanologia e Limnologia (AIOL), Napoli, Italy, 3-7 July 2006; Volume 19, pp. 483-487.

11. Spagnoli, F.; Bartholini, G.; Dinelli, E.; Marini, M.; Giordano, P. Early diagenesis of carbon and nutrients in sediments of the Gulf of Manfredonia (Southern Adriatic Sea). In Marine research@CNR; Brugnoli, E., Cavarretta, G., Mazzola, S., Trincardi, F., Ravaioli, M., Santoleri, R., Eds.; Consiglio Nazionale delle Ricerche, Dipartimento Terra \& Ambiente: Roma, Italy, 2011; Volume DTA/06-2011, pp. 459-474.

12. Spagnoli, F.; Bartholini, G.; Marini, M.; Giordano, P. Biogeochemical processes in sediments of the Manfredonia Gulf (Southern Adriatic Sea): Early diagenesis of carbon and nutrient and benthic exchange. Biogeosci. Discuss. 2004, 1, 803-823. [CrossRef]

13. Spagnoli, F.; Bartholini, G.; Marini, M.; Giordano, P.; McCorkle, D.; Fiesoletti, F.; Specchiulli, A. Early diagenesis and benthic fluxes in Manfredonia Gulf (Southern Adriatic Sea). Geochim. Cosmochim. Acta 2004, 68, 348.

14. Berelson, W.M.; Hammond, D.E.; Smith, K.L.; Jahnke, R.A.; Devol, A.H.; Hinga, K.R.; Sayles, F. In situ benthic flux measurement devices-bottom lander technology. Mar. Technol. Soc. J. 1987, 21, 26-32.

15. Buchholtz-ten Brink, M.R.; Gust, G.; Chavis, D. Calibration and performance of a stirred benthic chamber. Deep Sea Res. Part A Oceanogr. Res. Pap. 1989, 36, 1083-1101. [CrossRef]

16. Glud, R.N.; Forster, S.; Huettel, M. Influence of radial pressure gradients on solute exchange in stirred benthic chambers. Mar. Ecol. Prog. Ser. 1996, 141, 303-311. [CrossRef]

17. Greinert, J.; Linke, P.; Sweetman, A. Integrated Modular Systems for Monitoring of Ecosystem Functions in Deep-Sea Habitats with Relevance for Mining; MIDAS: Itasca, IL, USA, 2015.

18. Parker, W.; Doyle, K.; Parker, E.; Kershaw, P.; Malcolm, S.; Lomas, P.; Kershaw, P. Benthic interface studies with landers. Consideration of lander/interface interactions and their design implications. J. Exp. Mar. Boil. Ecol. 2003, 285, 179-190. [CrossRef]

19. Priede, I.G.; Addison, S.; Bradley, S.; Bagley, P.M.; Gray, P.; Yau, C.; Witte, U. Autonomous deep-ocean lander vehicles; modular approaches to design and operation. In Proceedings of the IEEE Oceanic Engineering Society (OCEANS'98), Nice, France, 28 September-1 October 1998; Volume 3, pp. 1238-1244.

20. Tengberg, A.; De Bovee, F.; Hall, P.; Berelson, W.; Chadwick, D.; Ciceri, G.; Crassous, P.; Devol, A.; Emerson, S.; Gage, J.; et al. Benthic chamber and profiling landers in oceanography-A review of design, technical solutions and functioning. Prog. Oceanogr. 1995, 35, 253-294. [CrossRef]

21. Tengberg, A.; Stahl, H.; Gust, G.; Müller, V.; Arning, U.; Andersson, H.; Hall, P. Intercalibration of benthic flux chambers I. Accuracy of flux measurements and influence of chamber hydrodynamics. Prog. Oceanogr. 2004, 60, 1-28. [CrossRef] 
22. Viollier, E.; Rabouille, C.; Apitz, S.; Breuer, E.; Chaillou, G.; Dedieu, K.; Furukawa, Y.; Grenz, C.; Hall, P.; Janssen, F.; et al. Benthic biogeochemistry: State of the art technologies and guidelines for the future of in situ survey. J. Exp. Mar. Boil. Ecol. 2003, 285, 5-31. [CrossRef]

23. Berg, P.; Glud, R.N.; Hume, A.; Ståhl, H.; Oguri, K.; Meyer, V.; Kitazato, H. Eddy correlation measurements of oxygen uptake in deep ocean sediments. Limnol. Oceanogr. Methods 2009, 7, 576-584. [CrossRef]

24. Berg, P.; Long, M.H.; Huettel, M.; Rheuban, J.E.; McGlathery, K.J.; Foreman, K.H.; Giblin, A.E.; Marino, R.; Howarth, R.W. Eddy correlation measurements of oxygen fluxes in permeable sediments exposed to varying current flow and light. Limnol. Oceanogr. 2013, 58, 1329-1343. [CrossRef]

25. Fones, G.R.; Davison, W.; Holby, O.; Thamdrup, B.; Jorgensen, B.B. High-resolution metal gradients measured by in situ DGT/DET deployment in Black Sea sediments using an autonomous benthic lander. Limnol. Oceanogr. 2001, 46, 982-988. [CrossRef]

26. Greeff, O.; Glud, R.N.; Gundersen, J.; Holby, O.; Jørgensen, B.B. A benthic lander for tracer studies in the sea bed: In situ measurements of sulfate reduction. Cont. Shelf Res. 1998, 18, 1581-1594. [CrossRef]

27. Miwa, T.; Iino, Y.; Tsuchiya, T.; Matsuura, M.; Takahashi, H.; Katsuragawa, M.; Yamamoto, H. Underwater observatory lander for the seafloor ecosystem monitoring using a video system. In Proceedings of the 2016 Techno-Ocean (Techno-Ocean), Kobe, Japan, 6-8 October 2016; pp. 333-336.

28. Best, M.M.; Favali, P.; Beranzoli, L.; Blandin, J.; Çağatay, N.M.; Cannat, M.; de Stigter, H. The EMSO-ERIC Pan-European Consortium: Data benefits and lessons learned as the legal entity forms. Mar. Technol. Soc. J. 2016, 50, 8-15. [CrossRef]

29. Chen, J.; Zhang, Q.; Zhang, A.; He, L.; Chen, Q. Sea trial and free-fall hydrodynamic research of a 7000-meter lander. In Proceedings of the OCEANS 2015-MTS/IEEE, Washington, DC, USA, 19-22 October 2015; pp. 1-5.

30. Chen, J.; Zhang, Q.; Zhang, A.; Tang, Y. 7000M lander design for hadal research. In Proceedings of the 2014 Oceans, St. John's, NL, Canada, 14-19 September 2014; pp. 1-4.

31. Hardy, K.; Cameron, J.; Herbst, L.; Bulman, T.; Pausch, S. Hadal landers: The Deepsea Challenge Ocean Trench Free Vehicles. In Proceedings of the 2013 OCEANS, San Diego, CA, USA, 23-27 September 2013; pp. 1-10.

32. Jamieson, A.J.; Fujii, T.; Solan, M.; Priede, I.G. HADEEP: Free-Falling Landers to the Deepest Places on Earth. Mar. Technol. Soc. J. 2009, 43, 151-160. [CrossRef]

33. Murashima, T.; Nakajoh, H.; Takami, H.; Yamauchi, N.; Miura, A.; Ishizuka, T. 11,000 m class free fall mooring system. In Proceedings of the Oceans 2009-Europe, Bremen, Germany, 11-14 May 2009; pp. 1-5.

34. Choi, J.K.; Fukuba, T.; Yamamoto, H.; Furushima, Y.; Miwa, T.; Kawaguchi, K. Pinpoint and Safe Installation of a Standalone Seafloor Observatory. In Proceedings of the 2018 OCEANS-MTS/IEEE Kobe Techno-Oceans (OTO), Kobe, Japan, 28-31 May 2018; pp. 1-4.

35. Pargett, D.M.; Jensen, S.D.; Roman, B.A.; Preston, C.M.; Ussler, W.; Girguis, P.R.; Scholin, C.A. Deep water instrument for microbial identification, quantification, and archiving. In Proceedings of the 2013 OCEANS, San Diego, CA, USA, 23-27 September 2013; pp. 1-6.

36. Wenzhöfer, F.; Wulff, T.; Floegel, S.; Sommer, S.; Waldmann, C. ROBEX-Innovative robotic technologies for ocean observations, a deep-sea demonstration mission. In Proceedings of the OCEANS 2016 MTS/IEEE, Monterey, CA, USA, 19-23 September 2016; pp. 1-8.

37. Williams, A.J. Expendable benthic lander (XBL). In Proceedings of the 2008 IEEE/OES US/EU-Baltic International Symposium, Tallinn, Estonia, 27-29 May 2008; pp. 1-8.

38. Berner, A. Early Diagenesis: A Theoretical Approach; Princeton University Press: Princeton, NJ, USA, 1980.

39. Hammond, D.E.; Fuller, C.; Harmon, D.; Hartman, B.; Korosec, M.; Miller, L.G.; Hager, S.W. Benthic fluxes in San Francisco bay. In Temporal Dynamics of an Estuary: San Francisco Bay; Springer: Dordrecht, The Netherlands, 1985; pp. 69-90.

40. Hammond, D.E.; McManus, J.; Berelson, W.M.; Kilgore, T.E.; Pope, R.H. Early diagenesis of organic material in equatorial Pacific sediments: Stoichiometry and kinetics. Deep Sea Res. 1996, 43, 1365-1412. [CrossRef]

41. Esposito, V.; Andaloro, F.; Canese, S.; Bortoluzzi, G.; Bo, M.; Di Bella, M.; Italiano, F.; Sabatino, G.; Battaglia, P.; Consoli, P.; et al. Exceptional discovery of a shallow-water hydrothermal site in the SW area of Basiluzzo islet (Aeolian archipelago, South Tyrrhenian Sea): An environment to preserve. PLoS ONE 2018, 13, e0190710. [CrossRef] [PubMed] 
42. Spagnoli, F.; Andaloro, F.; Canese, S.; Capaccioni, B.; Esposito, V.; Giordano, P.; Romeo, T.; Bortoluzzi, G. Nuove recenti conoscenze sul sistema idrotermale del complesso vulcanico dell'Isola di Panarea (Arcipelago delle Eolie, Mar Tirreno Meridionale) New recent insights of the hydrothermal system of the Panarea Island (Aeolian Archipelago, South Tyrrhenian Sea). Mem. Descr. Carta Geol. 2019, 105, 85-90.

43. Berelson, W.; Hammond, D.; Johnson, K.; Johnson, K. Benthic fluxes and the cycling of biogenic silica and carbon in two southern California borderland basins. Geochim. Cosmochim. Acta 1987, 51, 1345-1363. [CrossRef]

44. Cummins, K.M.; McManus, J.; Smith, G.; Spagnoli, F.; Hammond, D.E.; Cummins, K.M.; Berelson, W.M. Methods for measuring benthic nutrient flux on the California Margin: Comparing shipboard core incubations to in situ lander results. Limnol. Oceanogr. Methods 2004, 2, 146-159.

45. Hammond, D.; Giordani, P.; Berelson, W.; Poletti, R. Diagenesis of carbon and nutrients and benthic exchange in sediments of the Northern Adriatic Sea. Mar. Chem. 1999, 66, 53-79. [CrossRef]

46. Berelson, W.; Hammond, D. The calibration of a new free-vehicle benthic flux chamber for use in the deep sea. Deep. Sea Res. Part A Oceanogr. Res. Pap. 1986, 33, 1439-1454. [CrossRef]

47. Black, K.S.; Fones, G.R.; Peppe, O.C.; Kennedy, H.A.; Bentaleb, I. An autonomous benthic lander: Preliminary observations from the UK BENBO thematic programme. Cont. Shelf Res. 2001, 21, 859-877. [CrossRef]

48. Devol, A.H. Verification of flux measurements made with in situ benthic chambers. Deep. Sea Res. Part A Oceanogr. Res. Pap. 1987, 34, 1007-1026. [CrossRef]

49. Ferrón, S.; Alonso-Pérez, F.; Castro, C.G.; Ortega, T.; Pérez, F.F.; Ríos, A.F.; Forja, J.M. Hydrodynamic characterization and performance of an autonomous benthic chamber for use in coastal systems. Limnol. Oceanogr. Methods 2008, 6, 558-571. [CrossRef]

50. Ishida, H.; Watanabe, Y.; Fukuhara, T.; Kaneko, S.; Furusawa, K.; Shirayama, Y. In situ Enclosure Experiment Using a Benthic Chamber System to Assess the Effect of High Concentration of $\mathrm{CO}_{2}$ on Deep-Sea Benthic Communities. J. Oceanogr. 2005, 61, 835-843. [CrossRef]

51. Jahnke, R.; Christiansen, M. A free-vehicle benthic chamber instrument for sea floor studies. Deep. Sea Res. Part A Oceanogr. Res. Pap. 1989, 36, 625-637. [CrossRef]

52. Lee, J.S.; An, S.-U.; Park, Y.-G.; Kim, E.; Kim, D.; Kwon, J.N.; Kang, D.-J.; Noh, J.-H. Rates of total oxygen uptake of sediments and benthic nutrient fluxes measured using an in situ autonomous benthic chamber in the sediment of the slope off the southwestern part of Ulleung Basin, East Sea. Ocean Sci. J. 2015, 50, 581-588. [CrossRef]

53. Sayles, F.; Dickinson, W. The ROLAI ${ }^{2} \mathrm{D}$ lander: A benthic lander for the study of exchange across the sediment-water interface. Deep. Sea Res. Part A Oceanogr. Res. Pap. 1991, 38, 505-529. [CrossRef]

54. Smith, K.L.; Clifford, C.H.; Eliason, A.H.; Walden, B.; Rowe, G.T.; Teal, J.M. A free vehicle for measuring benthic community metabolism1. Limnol. Oceanogr. 1976, 21, 164-170. [CrossRef]

55. Smith, K.L., Jr.; White, G.A.; Laver, M.B. Oxygen uptake and nutrient exchange of sediments measured in situ using a free vehicle grab respirometer. Deep Sea Res. Part A Oceanogr. Res. Pap. 1979, 26, 337-346. [CrossRef]

56. Spagnoli, F.; Giuliani, G.; Martinotti, V.; Masini, L.; Penna, P. AMERIGO and CBA: A new lander and a new automatic benthic chamber for dissolved benthic flux measurements. In Proceedings of the 2018 IEEE International Workshop on Metrology for the Sea, (MetroSea 2018), Bari, Italy, 8-10 October 2018; ISBN 978-1-5386-7643-1.

57. Morris, R.; Hardy, K. Selecting an acoustic release for a mooring or lander. In Proceedings of the OCEANS 2017, Anchorage, AK, USA, 18-21 September 2017; pp. 1-5.

58. Phleger, C.F.; Soutar, A. Free vehicles and deep-sea biology. Am. Zool. 1971, 11, 409-418. [CrossRef]

59. Morse, J.W.; Boland, G.; Rowe, G.T. A 'gilled' benthic chamber for extended measurement of sediment-water fluxes. Mar. Chem. 1999, 66, 225-230. [CrossRef]

60. Giordano, P.; Spagnoli, F.; Marcaccio, M.; Marini, M.; Frascari, F.; Modica, A.; Rivas, G. Il Mar Piccolo di Taranto: Osservazioni preliminari sul ciclo dei nutrienti all'interfaccia acqua-Sedimento. Atti Della Assoc. Ital. Oceanol. Limnol. 2004, 17, 59-70.

61. Masini, L.; Spagnoli, F.; Marcaccio, M.; Frascari, F. Prototipo di Camera Bentica Automatica per Bacini Acquatici Continentali e Marini; Consiglio Nazionale delle Ricerche, Istituto di Geologia Marina: Bologna, Italy, 2001.

62. Berelson, W.; Hammond, D.; O’Neill, D.; Xu, X.-M.; Chin, C.; Zukin, J. Benthic fluxes and pore water studies from sediments of the central equatorial north Pacific: Nutrient diagenesis. Geochim. Cosmochim. Acta 1990, 54, 3001-3012. [CrossRef] 
63. Spagnoli, F. AMERIGO: A Deep Sea Lander. CNR Marine Research Activities and Technologies, Thematics: Technologies; Consiglio Nazionale delle Ricerche, Dipartimento Terra \& Ambiente: Rome, Italy, 2010.

64. Spagnoli, F.; Andresini, A.; Borgognoni, L.; Bortoluzzi, G.; Campanelli, A.; Canonico, C.; Ferrante, V.; Giuliani, G.; Giordano, P.; Greco, M.; et al. Campagna Oceanografica CASE4; Rapporto Finale di Crociera; ISMAR-CNR: Ancona, Italy, 2012.

65. Spagnoli, F.; Allende Ccori, J.; Andresini, A.; Borgognoni, L.; Ferrante, V.; Giordano, P.; Pignotti, E.; Zuzolo, M.G. Campagna Oceanografica PER1; Rapporto Finale di Crociera; CNR-ISMAR: Ancona, Italy, 2013; p. 33.

66. Spagnoli, F.; Ciceri, G.; Giuliani, G.; Martinotti, V.; Penna, P. AMERIGO: A new benthic lander for dissolved flux measurements at sediment-water-interface. In Proceedings of the Goldschmidt 2013, Florence, Italy, 25-30 August 2013; Volume 77, p. 2242.

67. Spagnoli, F.; Giuliani, G.; Penna, P.; Martinotti, V. AMERIGO, a lander for benthic flux and chemical and physical parameter measurements and for the sampling of water and sediment at the sediment-water interface. In Le Tecnologie del CNR per il Mare; Consiglio Nazionale delle Ricerche CNR: Roma, Italy, 2013.

68. Spagnoli, F.; Bartholini, G.; Capaccioni, B.; Giordano, P. Benthic Nutrient Fluxes in Central and Southern Adriatic and Ionian Seas. In Proceedings of the 40th CIESM Congress, Marseille, France, 28 October-1 November 2013.

69. Spagnoli, F.; Borgognoni, L.; Campanelli, A.; Ciceri, G.; Martinotti, V.; Giordano, P.; Giuliani, G.; Penna, P. A new biogeochemical method for the monitoring of possible seeps in marine CCS fields. In Proceedings of the Geoitalia 2013-Le Geoscienze per la Società, IX edizione del Forum Italiano di Scienze della Terra, Pisa, Italy, 16-18 Setptember 2013.

70. Spagnoli, F.; Ciceri, G.; Giordano, P.; Martinotti, V.; Politi, M. Experimental biogeochemical approach to the monitoring of baseline levels of $\mathrm{CO}_{2}$ fluxes at the sediment-water interface for CCS purpose. In Proceedings of the Geoitalia 2011, VIII Forum Italiano di Scienze della Terra, Torino, Italy, 19-23 September 2011.

71. Spagnoli, F.; Kaberi, H.; Giordano, P.; Zeri, C.; Borgognoni, L.; Bortoluzzi, G.; Campanelli, A.; Ferrante, V.; Giuliani, G.; Martinotti, V.; et al. Benthic fluxes of dissolved heavy metals in polluted sediments of the Adriatic Sea. In Proceedings of the Scientific Conference: Integrated Marine Research in the Mediterranean and the Black Sea, Bruxelles, Belgium, 7-9 December 2015; pp. 301-302, ISBN 978-960-9798-25-9.

72. Spagnoli, F.; Bartholini, G.; Giordano, P. Benthic fluxes and early diagenesis processes in Adriatic Sea. Sessione poster. In Proceedings of the Goldschmidt 2013, Florence, Italy, 25-30 August 2013.

73. Bortoluzzi, G.; Spagnoli, F.; Aliani, S.; Romeo, T.; Canese, S.; Esposito, V.; Grassi, M.; Masetti, G.; Dialti, L.; Cocchi, L.; et al. New geological, geophysical and biological insights on the hydrothermal system of the Panarea-Basiluzzo Volcanic complex (Aeolian Islands, Tyrrhenian Sea). In Proceedings of the SGI-SIMP, Milan, Italy, 10-12 September 2014.

74. Spagnoli, F.; Borgognoni, L.; Acri, F.; Caccamo, G.; De Marco, R.; Leonetti, M. Indagini del Fondale del Porto di Fano a Mezzo di Camera Bentica Valutazione Degli Effetti del Dragaggio sui Sedimenti Marini. Fase Post-Operam; Technical Report; Istituto di Scienze Marine del CNR: Ancona, Italy, 2016.

75. Spagnoli, F.; Giordano, P.; Borgognoni, L.; Acri, F. Studi di Carattere Ambientale Volti a Valutare le Dinamiche e gli Effetti Ambientali dei Sedimenti Marini Provenienti da Escavi Portuali. Valutazione degli Effetti del Dragaggio sui Sedimenti Marini. Fase Post-Operam; Technical Report; Istituto di Scienze Marine del CNR: Ancona, Italy, 2016.

76. Giordano, P.; Spagnoli, F.; Langone, L.; Miserocchi, S.; Ferrante, V.; Vasumini, I.; Graziani, G.; Savelli, F.; Dalpasso, E.; De Marco, M. Rapporto delle Attività di Campagna, Campagna RID16; Istituto di Scienze Marine: Venice, Italy, 2016.

77. Rovere, M.; Argnani, A.; Mercorella, A.; Spagnoli, F.; Frapiccini, E.; Pellegrini, C.; Ciccone, F.; Zaniboni, F.; Pagnone, G.; Paparo, M.A.; et al. Accordo Operativo 2016 tra Consiglio Nazionale delle Ricerche-Istituto di Scienze Marine (ISMAR CNR) e Ministero dello Sviluppo Economico, Direzione Generale per la Sicurezza Anche Ambientale delle Attività Minerarie ed Energetiche-Ufficio Nazionale Minerario per gli Idrocarburi e le Georisorse (DGS-UNMIG); Istituto di Scienze Marine di Bologna: Bologna, Italy, 2018.

78. Frascari, F.; Spagnoli, F.; Marcaccio, M.; Giordano, P. Anomalous Po River flood event effects on sediments and the water column of the northwestern Adriatic Sea. Clim. Res. 2006, 31, 151-165. [CrossRef]

79. Spagnoli, F.; Dinelli, E.; Giordano, P.; Marcaccio, M.; Zaffagnini, F.; Frascari, F. Sedimentological, biogeochemical and mineralogical facies of Northern and Central Western Adriatic Sea. J. Mar. Syst. 2014, 139, 183-203. [CrossRef] 
80. Spagnoli, F.; Dell'Anno, A.; De Marco, A.; Dinelli, E.; Fabiano, M.; Gadaleta, M.V.; Ianni, C.; LoIacono, F.; Manini, E.; Marini, M.; et al. Biogeochemistry, grain size and mineralogy of the central and southern Adriatic Sea sediments: A review. Chem. Ecol. 2010, 26, 19-44. [CrossRef]

81. Spagnoli, F.; Frascari, F.; Marcaccio, M.; Bergamini, M.C. Early diagenesis and nutrient benthic fluxes in the Adriatic Sea. Geophys. Res. Abstr. 2003, 5, 12257.

82. Capet, A.; Lazzari, P.; Spagnoli, F.; Bolzon, G.; Solidoro, C. Benthic contributions to Adriatic and Mediterranean biogeochemical cycles. EGU Gen. Assem. Conf. Abstr. 2017, 19, 17596.

(C) 2019 by the authors. Licensee MDPI, Basel, Switzerland. This article is an open access article distributed under the terms and conditions of the Creative Commons Attribution (CC BY) license (http://creativecommons.org/licenses/by/4.0/). 